\title{
Organic-carbon deposition and costal upwelling at mid-latitude during the Upper Ordovician (Late Katian): a case study from the Welsh Basin, UK.
}

\author{
T. J. Challands ${ }^{\text {a }} *$ H. A. Armstrong ${ }^{a}$ D. P. Maloney ${ }^{a}$ \\ J.R. Davies ${ }^{b}$ D. Wilson ${ }^{b}$ A. W. Owen ${ }^{c}$ \\ ${ }^{a}$ Department of Earth Sciences, Durham University, Science Labs, South Road, \\ Durham, DH1 3LE UK \\ ${ }^{\mathrm{b}}$ British Geological Survey, Kingsley Dunham Centre, Keyworth, Nottingham \\ NG12 $5 G G U K$ \\ ${ }^{\mathrm{c}}$ Department of Geographical Earth Sciences, University of Glasgow, Gregory \\ Building, Lilybank Gardens, Glasgow, G12 8QQ UK
}

\begin{abstract}
A lack of stratigraphical, sedimentological and geochemical data for sediment accumulation rates and indicators of productivity and anoxia means that causative models for ancient black shales are largely inferred from modern settings. Coastal upwelling has been suggested as a general hypothesis for Ordovician black shale deposition within the Iapetus Ocean, but has not been directly tested. Despite anchizone metamorphism we utilize a suite of geological and geochemical environmental proxy data (TOC $\%, \delta{ }^{13} \mathrm{C}_{\text {org }}, \mathrm{Ba} / \mathrm{Al}, \mathrm{P}$ ) to elucidate the origin of grey-black shale cycles within the upper Katian succession of the Welsh Basin. Organic carbon (OC)-rich layers were periods of high photic productivity (higher TOC \%), with ${ }^{12} \mathrm{C}$ and $\mathrm{Ba}$ enrichment, comparable to high productivity events in modern coastal upwelling systems. Values are consistent with those from margins where sedimentation rates are high (e.g. Gulf of California). The inter-bedded grey shales have low TOC $\%$ more positive $\delta^{13} \mathrm{C}_{\text {org }}$ and lower $\mathrm{Ba}$ and are interpreted as low productivity events. Thalassinoides, Planolites and Chondrites trace fossil biofacies indicate changing seafloor oxygen levels. These show predominantly dysoxic conditions even during the deposition of OC-poor grey shales. During deposition of a single OC-rich event, oxygen levels declined at the sea floor before the deposition of the OC-rich layers. Full anoxia was established early on in the deposition of OC-layers and the return to more oxic conditions was rapid though fluctuating, coincident with the return of grey shale deposition. This pattern suggests OC accumulation at the seafloor resulted from a complex interaction of productivity and preservation. None of the widely used trace element redox proxies are reliable in anchizone metamorphic rocks. Climate sensitive detrital proxies $(\mathrm{K} / \mathrm{Al}$ and $\mathrm{Ti} / \mathrm{Al})$
\end{abstract}


indicate arid-temperate conditions in the basin hinterland during the deposition of the OC-rich layers. The Welsh Basin was situated on the southern margin of the Iapetus Ocean in $\left(30^{\circ} \mathrm{S}\right)$ beneath the prevailing $\mathrm{SE}$ trade winds. The intensification of upwelling prior to the Hirnantian glaciation likely resulted from a strengthening of the trade winds, associated with a stepped increase in ice volume, and a more arid local climate.

Key words: Ashgill, Upper Ordovician, Katian, black shale, $\delta^{13} \mathrm{C}_{\text {org }}$, trace metal, redox, upwelling, TOC, climate

\section{Introduction}

2 Black shales provide important records of climate and atmosphere-ocean interactions. The Early Palaeozoic oceans differed to the Mesozoic and younger oceans because they experienced a mild greenhouse climate (Berner, 1994; Berner and Kothavala, 2001; Yapp and Poths, 1992) and were prone to permanent anoxia (Leggett, 1980). However, black shales deposited in the Early Palaeozoic provide a detailed record of climate processes provided the mechanism for their formation can be constrained. Under such different climatic conditions it is necessary to determine if the processes that formed Mesozoic to modern ocean black shales are applicable to Palaeozoic black shales too. Processes for black shale formation include 1) the Runoff model (e.g. Beckmann et al., 2005; Bjerrum et al., 2006), dominant at tropical latitudes, whereby increased continental runoff introduces nutrients, increases productivity and organic carbon (OC) export, 2) the Upwelling model (e.g. Parrish, 1982; Hay and Brock, 1992; Pope and Steffen, 2003) dominant at mid- to high latitudes in trade wind zones and 3) the Transgressive model (Leggett, 1980) whereby expansion of the deep ocean oxygen minimum zone during sea-level rise promotes $\mathrm{OC}$ preservation in high productivity shelf environments.

The Transgressive model with unrestricted oceans may explain thick black shales in Lower Palaeozoic basins (Leggett, 1980; Page et al., 2007) but does not explain variation in productivity within black shale successions, and in fact assumes it to be effectively constant (Berry and Wilde (1978) p. 271; Leggett (1980), p.150). Black shale deposition is also not restricted to abyssal depths or transgressive successions in the Early Palaeozoic. For example, the upper Katian (Rawtheyan - Hirnantian British Stages) succession of Dob's Linn, Scotland, located on the northern margin of the Iapetus Ocean contains thin $(<30 \mathrm{~cm}$ thick) black shale units alternating with grey shale. These

* Corresponding author

Email address: t.j.challands@durham.ac.uk (T. J. Challands). 
were deposited at a time of increased productivity (Armstrong and Coe, 1997) and global eustatic, glacially-induced regression when the Iapetus Ocean was much narrower and likely more restricted than has been previously considered (Armstrong and Owen, 2002). Two oceanic events have been recognized in the Dob's Linn succession (Fig. 1). The first, in the mid Katian (StreffordianPusgillian boundary), is the sudden change from anoxic to oxic conditions and the replacement of black with grey shales. This has been interpreted as the onset of glacially-induced thermohaline circulation (Armstrong and Coe, 1997). The second is the re-appearance of discrete black shale units within predominantly grey shales during the upper Katian (anceps Biozone), considered indicative of climatically-forced, Monterey-type processes reflecting upwelling (Armstrong and Coe, 1997). The presence of these oceanographic events in the Welsh Basin, contemporaneous with Dob's Linn, demonstrate they were Iapetus Ocean-wide and reflect fundamental changes in the climate-ocean system before the onset of glaciation.

Oceanic upwelling systems have also been identified from lower Katian radiolarian cherts along the northern Iapetus Ocean (Pope and Steffen, 2003) and in Wales by the presence of phosphorites (e.g. Cave (1965)). The latter were compared to phosphorites forming today at shelf-slope depths off the California coast and attributed to climatic factors reflecting an absence of currents or weak offshore winds or the presence or basin restriction behind a submarine ridge.

In this case study we use a suite of proxy data to test an upwelling origin for the upper Katian black shale units within the Welsh Basin. Despite greenschist facies metamorphism, we have been able to reconstruct the palaeoenvironmental conditions during deposition from proxy data. We show that coastal upwelling was the primary cause of organic carbon (OC) enrichment of the sediments, likely driven by changes in the strength of the prevailing trade winds. This hypothesis is consistent with known patterns of Upper Ordovician climate change associated with the developing Hirnantian glaciation.

\section{Regional Geology of the Ordovician of the Welsh Basin}

Major oceanic events can also be identified in the Welsh Basin, that lay on the southern margin of the Iapetus Ocean. In Wales these events are found in the mid-upper Katian (linearis - complanatus graptolite Biozones and the anceps graptolite Biozones; spinifera and umbilicata chitinozoan Biozone respectively). At the first event, anoxic conditions were terminated and the succession changes to predominantly grey in colour (see below) and burrow mottled. These grey shale units are mapped regionally as the Nantmel Mudstones Formation (Davies et al. (2003); Fig. 2). The upper Katian event is recognised 
in the "Red Vein" which contains distinctive alternating black laminated and grey burrow mottled siltstone and mudstones.

The Red Vein (Fig. 2) outcrops from the Cadair Idris region in the north, south to Rhayader and Builth Wells regions and further west around Newcastle Emlyn and north of Cardigan (British Geological Survey Llangranog 1:50 000 scale Sheet number 194; 2003). This distinct unit was first recognized in the Cadair Idris area by Pugh (1923) and termed on account of oxidation of the abundant iron sulphide it contains. Three separate OC-rich laminated units have been recognized in the Rhayader, Builth Wells and Llangranog regions (Davies et al., 1997, 2004, 2006) and are interpreted as laminated hemipelagites (LH) (Davies et al., 1997). They consist of thin alternating laminae of dark grey, OC-rich material and medium grey OC-poor mudstone. On regional maps of these areas they are termed LH'-LH"' (British Geological Survey Rhayader 1:50 000 scale Sheet numbers 178 and 179; 1997, British Geological Survey Builth Wells 1:50 000 scale Sheet number 196; 2004, British Geological Survey Llangranog 1:50 000 scale Sheet number 194; 2006).

The LH units are interbedded with grey burrow mottled fine sandstones, siltstones and mudstones up to $25 \mathrm{~m}$ thick that have been interpreted as fine grained distal turbidites resulting from periodic influx of coarser material brought in by weak turbidity currents (Davies et al., 2003, 2004). Phosphatic nodules up to $1 \mathrm{~m}$ in length and phosphate horizons up to $10 \mathrm{~cm}$ thick are present in the organic-rich and organic-poor facies. Dark, diffuse fine-grained phosphatic layers up to $10 \mathrm{~mm}$ thick are more frequent in the OC-rich facies and less common in the OC-poor facies where they occur in light-grey silty mud layers.

The thermal history of the Ordovician of the Welsh Basin is reasonably well constrained, primarily based on illite crystallinity from shales, and indicates a regional record of diagenetic to epizone facies metamorphism (Roberts et al., 1996; Bevins and Robinson, 1988; Robinson and Bevins, 1986; Fettes et al., 1985). The Nantmel Mudstones Formation immediately adjacent to the studied area (British Geological Survey 1:50000 Sheet 193, Cardigan and Dinas Island) are of low anchizone grade. Dariwillian - lower Katian aged shales immediately south of Cardigan, have experienced late diagenetic to epizone temperatures $\left(200-300^{\circ} \mathrm{C}\right.$ ) (Lev et al., 2008) indicating burial to $c .4-6 \mathrm{~km}$ using a geothermal gradient of $c .50^{\circ} \mathrm{C} / \mathrm{km}$ (Bevins and Merriman, 1988; Bottrell et al., 1990; Roberts et al., 1991).

The onset of OC-rich deposition in the Welsh Basin is dated by the first appearance of the Avalonian chitinozoan index taxon Bursachitina umbilicata as mid-Rawtheyan (Upper Katian) (see Fig. 1) and the Ancyrochitina merga subzone is recognized in $\mathrm{LH}^{2}$. The Rawtheyan-Hirnantian boundary is placed $30 \mathrm{~m}$ above the top of $\mathrm{LH}^{3}$ at the abrupt transition from bioturbated sediment 
to non-bioturbated sediment and is marked by the influx of silty facies devoid of macrofossils and infauna characteristic of the overlying Yr Allt Formation.

\section{Methods and materials}

The best sections through the Red Vein are exposed in cliff sections along the coast of Cardigan Bay (Fig. 2). Accessibility is an issue and sections that are safe and allow optimum exposure of OC-Poor and OC-rich facies have had to be selected: Aberporth (SN 625 515), Tresaith (SN 280 516) and Traeth Penbryn (SN 289 522) (see Fig. 2). In the absence of significant gross lithological differences these sections are considered to be representative of LH horizons that could not be sampled. The same sections for trace fossil analysis and geochemical analysis could not be used for reasons of access. All trace fossil data was collected from $\mathrm{LH}^{0}$ at Aberporth (SN 625 515), two sections spanning the lower and upper parts of $\mathrm{LH}^{0}$ are conflated to a single composite section (Fig. 4). This $6.4 \mathrm{~m}$-thick section was sub-sampled over six $40 \mathrm{~cm}$ intervals, each separated by $1 \mathrm{~m}$. Geochemical samples were collected from two $5 \mathrm{~m}$ sections spanning the upper and lower boundaries of $\mathrm{LH}^{1}$, the lower boundary at Tresaith (SN 280 516) and the upper boundary at Traeth Penbryn (SN 289 522; see Fig. 2).

Samples for trace element analysis were taken from organic-rich horizons at the specified localities at $20 \mathrm{~cm}$ sample intervals. There was no evidence at the sampling site of secondary mineralisation and all samples were prepared from fresh specimens with no surface alteration or internal fracturing. Powders were then drilled from samples using a tungsten carbide drill bit. Matrix effects were considered negligible due to the fine-grained nature of the samples. Sub-samples were taken from each sample for trace element and stable isotopic analysis. Sample digestion was carried out using $\mathrm{HF}^{-\mathrm{HNO}_{3}}$ standard acid digestion techniques for ICP-MS following the procedure of (Ottley et al., 2003). A Perkin Elmer-Sciex Elan 6000 ICP-MS used in conjunction with a Cetac Direct Injection Nebuliser and a Cetac Aridius Desolvating Nebuliser was used for analysis of trace elements. The machine was calibrated using international rock standards W2, BHV01, AGV1, Be-N, NBS688 and BIR-1 and shale standards ScO-1, MAG-1 and SGR-1 were also used for initial comparison of sample shale values. All samples were analysed over three separate runs and reproducibility throughout runs was monitored using SGR-1 (see Table $1)$. Relative standard deviation $(\sigma /$ mean $\times 100)$ was less than $11 \%$ in all runs. Internal precision for individual analyses was greater than $95 \%$. Normalisation to $\mathrm{Al}$ is a standard procedure for comparing element proportions, particularly where organic matter content is variable (e.g., Tribovillard et al., 2005). Certain elements e.g. Ni are traditionally plotted against other detrital indicators e.g. Co and this is also carried out where appropriate. 
All $\delta^{13} \mathrm{C}_{\text {org }}$ and TOC $\%$ measurements were made on a Thermo Finnigan MAT 253 Stable Isotope Mass spectrometer at Durham University, Department of Earth Sciences. TOC \% analysis of samples from 779.5-794.5 cm from the base of $\mathrm{LH}^{1}$ were conducted at Newcastle University Department of Civil Engineering and Geosciences using Rock Eval (6) Pyrolysis. Urea ${ }_{2}, \mathrm{CH}-7$ and CH-6 standards were used for machine calibration and standard deviation was less than 0.15 per mil for all standards.

\subsection{Redox proxies}

3.1.0.1 Trace fossils - The application of analysis of trace fossil assemblages and the degree of bioturbation has proven a strong tool for determining fluctuations in sediment and basin oxygenation e.g. Savrda and Bottjer (1994); Ekdale and Mason (1988); Savrda (1995); Löwemark et al. (2004). Ichnogenera presence-absence, burrow diameter and bioturbation index data were collected in line with standard procedures (Savrda and Bottjer, 1994; Savrda, 1995; Löwemark et al., 2004) at centimetre-resolution in each sub-section.

3.1.0.2 Trace elements The biological pump heavily influences the cycling, concentration and residence times of the redox-sensitive and sulphideforming trace elements $(\mathrm{Cu}, \mathrm{Cr}, \mathrm{Ni}, \mathrm{V}, \mathrm{Cd}, \mathrm{Mo}$ and $\mathrm{U}$ ) (Tribovillard et al., 2005). These elements form sulphides and complexes with organic matter under reducing conditions and OC-rich sediments are enriched in these metals (De La Rocha, 2004; Tribovillard et al., 2005, and references therein).

However some of these elements show significant mobility during late diagenesis to low grade metamorphic conditions. For example, at these grades $\mathrm{V}$ becomes mobile and complexes with illite (Peacor et al., 2000) rendering the frequently used redox proxies $\mathrm{V} /(\mathrm{V}+\mathrm{Ni})$ and $\mathrm{V} / \mathrm{Cr}$ as unreliable. Uranium is also mobilized and enriched, whilst $\mathrm{Th}$ is depleted during the formation of illite at low metamorphic grades (Hannigan and Basu, 1998). Nickel has been regarded as a reliable redox proxy in organic-rich shales (Jones and Manning, 1994) and has not been demonstrated to be mobile during low metamorphism.

\subsection{Productivity proxies}

3.2.0.3 $\delta^{13} \mathbf{C}_{\text {org }}$ The $\delta^{13} \mathrm{C}_{\text {org }}$ values of sedimentary organic matter are controlled by a number of factors including organic matter composition and cell growth rates (for a review see Freeman, 2001; Maslin and Swann, 2005, and references therein). In the open ocean, sedimentary organic matter is derived 
from marine and terrestrial sources. In pre-Devonian time there was no extensive terrestrial vegetation (Peters-Kottig et al., 2006) and organic matter in Ordovician rocks can therefore be considered entirely marine in origin. Cell growth rates cannot be constrained in ancient samples. Bulk sediment $\delta^{13} \mathrm{C}_{\text {org }}$ values are therefore only considered indicative of shifts in mean oceanic isotopic composition.

Illite crystallinity data indicate a regional pattern of low to high anchizone metapeletic zone for the Cardigan area (Davies et al., 2003). $\delta^{13} \mathrm{C}_{\text {org }}$ values have been shown to yield an unaltered environmental signal in similar greenschist facies rocks at Dob's Linn (Underwood et al., 1997). One whole rock sample from each of the four laminated hemipelagite units was measured for $\delta^{13} \mathrm{C}_{\text {org }}$ and eighteen samples were measured through $\mathrm{LH}^{1}$ to investigate higher frequency patterns. In addition to this, nine samples were taken from OC-poor facies between the LH units.

3.2.0.4 Total organic carbon (TOC \%) TOC \% is known to correlate with more direct measures of photosynthetic primary productivity such as total chlorophyll-a or total steryl chlorine esters (Nara et al., 2005) and organic mass accumulation rate (Meyers and Arnaboldi, 2005; Kuypers et al., 2004, 2002; Twichell and Diester-Haass, 2002; Vilinski and Domack, 1998; Tyson, 1995) and can therefore be used as a proxy for productivity when supported by other proxy data e.g. Ba.

3.2.0.5 Trace elements The strong correlation between $\mathrm{Ba}$ and organic matter in marine sediments has led Ba values to be used to infer past export production (De La Rocha, 2004). Dysoxic conditions are characterized by relatively low Ba concentrations ( $<500$ ppm), increased Cd and U (Prakash Babu et al., 2002). Though frequently used as a palaeoproductivity indicator, Ba has been found to be associated with sapropels formed in euxinic basins (Brumsack, 2006) and in such environments precipitates as barium-sulphides. Ba is thus an unreliable indicator of productivity if euxinia can be demonstrated (Shimmield, 1992; Prakash Babu et al., 2002). Ba is typically measured as a ratio against Th which is taken to represent terrigenous detrital input (Shimmield, 1992). Due to the mobility of Th in low grade metamorphic rocks we have normalized to $\mathrm{Al}$ which is also considered to be a detrital indicator (Tribovillard et al., 2005). We also plot raw Ba abundance (ppm) to test if an increase in $\mathrm{Ba} / \mathrm{Al}$ is the product of decreasing $\mathrm{Al}$. 


\subsection{Climate sensitive detrital input proxies, $K / A l$ and $\mathrm{Ti} / \mathrm{Al}$}

$\mathrm{K}$ and $\mathrm{Al}$ are mainly confined to the fine-grained aluminosilicate fraction, clay minerals and feldspars. Kaolinite which is rich in $\mathrm{Al}$ forms by intense chemical weathering under humid conditions whereas illites, which are rich in $\mathrm{K}$, form under less humid weathering conditions (Beckmann et al., 2005; Tribovillard et al., 2005). Ti is concentrated in heavy minerals and is often transported as part of the wind blown detritus, considered indicative of weathering in arid environments. The $\mathrm{K} / \mathrm{Al}$ ratios are therefore used as a proxy of temperate to humid weathering and, similarly, $\mathrm{Ti} / \mathrm{Al}$ may be regarded as a proxy for arid to humid weathering (Yarincik et al., 2000).

\section{Results}

In the present study, four separate OC-rich laminated horizons were recognized in the Llangranog region. The new LH horizon is stratigraphically lower than the three previously recognized LH units and, following the British Geological Survey numbering convention for these units, has been named $\mathrm{LH}^{0}$. From here on, $\mathrm{LH}$ are referred to numerically e.g. $\mathrm{LH}^{1}$, rather than using 'primes' e.g. LH', to avoid inconsistency in labelling. The LH in the Llangranog region range in thickness from between 10-36 m. Laminated OC-rich layers contain abundant pyrite framboids and small nodules up to $1 \mathrm{~mm}$ in length alongside finely-disseminated pyrite in the OC-rich silty-mud fraction. The OC-rich laminated horizons are composed of a fine clay matrix and angular quartz grains up to $0.25 \mathrm{~mm}$ and fine, platy muscovite and chlorite grains up to $0.175 \mathrm{~mm}$ long. The medium grey mudstone component occasionally contains thin fining-up sequences from silt to mudstone and occasional very thin $(<2 \mathrm{~mm})$ fine-grained sand and are interpreted as hemiturbidites (Stow and Wetzl, 1987) deposited in a slope-apron system (Davies et al., 2004). The absence of significant grain-size variations between the OC-poor grey mudstones and OC-rich units suggest the increase in OC content of the sediment was independent of factors affecting sediment supply.

\subsection{Productivity proxies: $\mathrm{TOC} \%, \delta^{13} \mathrm{C}_{\text {org }}, \mathrm{Ba} / \mathrm{Al}$}

TOC $\%$ values increase during deposition of each organic-rich laminated hemipelagite unit. The maximum TOC \% value of $0.51 \%$ occurs in $\mathrm{LH}^{1}$ (mean value for all $\mathrm{LH}$ units $=0.37 \%$ ) whereas the minimum for OC-poor oxic facies is $0.08 \%$ (Pen y Craig, SN 221252 ) (mean for oxic facies $=0.27 \%$ ) (fig. 3) compared to 2 to $8 \%$ for none metamorphosed black shales from the Katian of the Gond- 
wanan margin. A reasonable negative correlation between TOC and $\delta^{13} \mathrm{C}_{\text {org }}$ exists $\left(\mathrm{r}^{2}=0.4\right)$, high TOC values correspond to more negative $\delta^{13} \mathrm{C}_{\text {org }}$ values (Figs. 3, 5, 6 a).

$\delta^{13} \mathrm{C}_{\text {org }}$ values fluctuate by up to 2.85 per mil but display a decreasing trend from the base of the measured section at Gwbert Hotel (SN 160 509) from -28.10 per mil to -31.81 during the deposition of OC-rich facies $\left(\mathrm{LH}^{1} ; \mathrm{SN} 280\right.$ 363 516; Fig. 3). Each organic-rich event is characterized by a distinct negative excursion of 1 per mil. ${ }^{13} \mathrm{C}_{\text {org }}$ values for each $\mathrm{LH}$ unit are between -31.4 per mil $\left(\mathrm{LH}^{1}\right)$ and -31.9 per mil $\left(\mathrm{LH}^{3}\right.$ (mean -31.65 per mil) compared to a mean value of -30.74 per mil for organic-poor oxic facies (Fig. 5).

$\mathrm{Ba} / \mathrm{Al}$ values in OC-rich facies vary between $2.5 \times 10^{-3}$ to $3.1 \times 10^{-3}$ and the mean is higher (mean $=2.8 \times 10^{-3}$ ) than the mean for OC-poor facies $\left(\min .=1.8 \times 10^{-3}\right.$, max. $=4.0 \times 10^{-3}$, mean $\left.=2.7 \times 10^{-3}\right)$. Values remain relatively constant in the lower $140 \mathrm{~cm}$ of $\mathrm{LH}^{1}$. There is an abrupt decrease from $3.0 \times 10^{-3}$ to $2.7 \times 10^{-3}$ at $140 \mathrm{~cm}$ (Fig. 5). Throughout the entire section, $\mathrm{Ba} / \mathrm{Al}$ ratios and $\mathrm{Ba}$ values for samples from OC-poor and OC-rich facies are statistically different for the mean and variance (Table 2). Correlation of Ba with $\mathrm{Al}$ is good ( $\mathrm{r}^{2}=0.6$; Fig. $\left.6 \mathrm{~b}\right)$. There is no correlation between $\mathrm{Ba} / \mathrm{Al}$ and TOC (Fig. 6 c).

\subsection{Redox proxies}

4.2.0.6 Trace fossils Sub-sections 1-4 (Fig. 4) represent a transect through $\mathrm{LH}^{0}$. The burrow diametre reflects changing ichnogeneric content. Thalassinoides was not recorded in the $\mathrm{LH}^{0}$ section but is present with Planolites and Chondrites elsewhere in the OC-poor facies. Here, BI and maximum burrow diametre are high $(\mathrm{BI}=4$, max. burrow diametre $=\geq 5 \mathrm{~mm})$. These conditions are rapidly replaced by a Planolites and Chondrites assemblage with BI $\leq 4$ and maximum burrow diametre $\leq 6 \mathrm{~mm}$ (sub-sections 1-3; fig. 4). At 4.2 $\mathrm{m}$ above the base of the section $(0 \mathrm{~cm}$ sub-section 4$)$ Chondrites is the only ichnotaxon present and $\mathrm{BI}$ and burrow diametre are correspondingly low (BI $=\leq 2$, max. burrow diametre $\leq 2 \mathrm{~mm}$ ). At levels between $20 \mathrm{~cm}$ to $38 \mathrm{~cm}$ in sub-section 4 and $22 \mathrm{~cm}$ to $38 \mathrm{~cm}$ sub-section 5 strata are devoid of trace fossils. Between the top of sub-section 4 and the bottom of sub-section 5 no burrowing infauna are recorded. At the top of sub-section 5 (1.42 m below the top of $\mathrm{LH}^{0}$ Aberporth section 2; Fig. 4) Planolites returns with a corresponding increase in burrow diametres and $\mathrm{BI}(\mathrm{BI}=\leq 4$, max. burrow diametre $=$ $3 \mathrm{~mm})$. 
4.2.0.7 Geochemical redox proxies; Ni/Co All Ni values vary from 10.32 to $92.25 \mathrm{ppm}$ and are typical for Phanerozoic upwelling shales (average shale $=68 \mathrm{ppm}$, see Table 3$)$. Values for samples at $780 \mathrm{~cm}$ and $780.75 \mathrm{~cm}$ above the base of the measured section are anomalously low (10.32 and 14.24 respectively). Values for $\mathrm{Ni} / \mathrm{Co}$ fall between 1.37 and $6.69($ mean $=2.88)$. The mean value for Ni/Co throughout OC-rich $\mathrm{LH}$ is 2.61 (1.36 to 3.89) whilst values in the OC-poor facies range have a mean of 3.28 (1.91 to 6.69). Crossing the base of the $\mathrm{LH}, \mathrm{Ni} / \mathrm{Co}$ values fall abruptly to 1.03 (Fig. 5). Through $\mathrm{LH}^{1}$ values rise towards the centre (up to 3.31) and then decline towards the boundary. $2.5 \mathrm{~cm}$ below the top of the $\mathrm{LH}^{1}, \mathrm{Ni} / \mathrm{Co}$ values fall to 1.4 . In the base of the overlying OC-poor shales this value rises abruptly to 6.7.

$\mathrm{Ni} / \mathrm{Al}$ shows a pattern difference to $\mathrm{Ni} / \mathrm{Co}$. Values vary between $0.1 \times 10^{-3}$ to $11.4 \times 10^{-4}\left(\right.$ mean $\left.=4.71 .1 \times 10^{-4}\right)$ throughout the entire section $($ Fig. 5$)$ whereas in the OC-poor facies values vary from $2.3 \times 10^{-4}$ to $8.0 \times 10^{-4}$ (mean $\left.=4.2 \times 10^{-4}\right)$. In the OC-rich facies values from $1.9 \times 10^{-4}$ to $11.4 \times 10^{-4}$ (mean $\left.=5.0 \times 10^{-4}\right)$. At the base of $\mathrm{LH}^{1}, \mathrm{Ni} / \mathrm{Al}$ values increase by $1.0 \times 10^{-4}(4.0$ $\times 10^{-4}$ to $\left.5.0 \times 10^{-4}\right)$. Values gradually rise to a maximum of $10.0 \times 10^{-4}$ at the OC-rich - OC-poor boundary at $779.5 \mathrm{~cm}$ after which they decrease. In the OC-poor facies, values rise again fluctuating between $8.0 \times 10^{-4}(920 \mathrm{~cm})$ and $3.0 \times 10^{-4}(800 \mathrm{~cm})$. Ni shows a strong positive correlation with Co $\left(\mathrm{r}^{2}=0.6\right.$; Fig. 7 a), however, $\mathrm{Ni}$ abundance is not strongly controlled by $\mathrm{Al}\left(\mathrm{r}^{2}=0.2\right.$; Fig. $7 \mathrm{~b}$ ) but demonstrates a positive relationship with TOC \% but with low correlation $\left(\mathrm{r}^{2}=0.2\right.$; Fig. $\left.7 \mathrm{c}\right)$.

\subsection{Weathering regime proxies, K/Al. Ti/Al}

During organic-rich sedimentation there is a slight increase $\mathrm{K} / \mathrm{Al}$ values increase by $0.007(\max .=0.294, \min .=0.248$, OC-rich mean $=0.264$, OC-poor mean $=0.258)$ whereas $\mathrm{Ti} / \mathrm{Al}$ values do not vary significantly throughout the section $(\max .=0.040$, min. $=0.032$, OC-rich mean $=0.034$, OC-poor mean $=0.035)$. Peak values of 0.34 and 0.049 for $\mathrm{K} / \mathrm{Al}$ and $\mathrm{Ti} / \mathrm{Al}$ respectively are observed just within the organic poor facies at $788.25 \mathrm{~cm}$ (Fig. 5). 


\section{Preservation and productivity during deposition of OC-rich lam- inated hemipelagite}

\subsection{Synchroneity of productivity, preservation and redox}

In the Late Katian of the Welsh Basin, Thalassinoides, Planolites and Chondrites dominate the burrow mottling of the sediment up to $2.8 \mathrm{~m}$ below the base of $\mathrm{LH}^{0}$ with high burrow diametre and $\mathrm{BI}$ values. $2.8 \mathrm{~m}$ below the base of $\mathrm{LH}^{0}$ Thalassinoides disappears entirely and $1.8 \mathrm{~m}$ above the base of $\mathrm{LH}^{0}$ all burrowing disappears. These trace fossil associations can be related to models proposed by Rhoads and Morse (1971) and Sageman et al. (1991) for the interpretation of oxygen deficient biofacies which can be used to investigate relative timing of anoxia and LH deposition. Three distinct biofacies were recognized in the Rhoads and Morse (1971) model; anaerobic, dysaerobic and aerobic, each defined by a specific fauna and characteristic sedimentary fabrics. Similarly, Sageman et al. (1991) refined the scheme dividing it into seven biofacies levels corresponding to oxygenation. Level 1 and 2 indicate anaerobic conditions, level 2-6 dysaerobic conditions and level 7 normal aerobic conditions (Fig. 8).

The presence and absence of the three dominant ichnotaxa through $\mathrm{LH}^{0}$ allows the recognition of three distinct ichnocoenoses that correspond to the biofacies levels described by Sageman et al. (1991): 1) Thalassinoides ichnocoenosis (biofacies level 6+), 2) Planolites ichnocoenosis (biofacies level 4-5, and 3) Chondrites ichnocoenosis (biofacies level 3). Oxygen depletion was initiated prior to the appearance of macroscopic OC, indicated by the disappearance of Thalassinoides, and declined gradually to fully anoxic conditions $1.4 \mathrm{~m}$ into the event. In the upper part of $\mathrm{LH}^{0}, \mathrm{O}_{2}$ levels fluctuated between dysoxic (Chondrites ichnocoenosis, biofacies level 3) and fully anoxic conditions. $\mathrm{O}_{2}$ levels rise through into the overlying OC-poor shales reaching levels close to the dysoxic-oxic boundary as marked by the reestablishment of Thalassinoides. Ichnocoenosis boundaries do not coincide with the boundaries of the LH suggesting OC burial flux/increased productivity and redox were not synchronous.

During the deposition of LH facies we observe, 1) higher TOC \% values which correspond to more negative $\delta^{13} \mathrm{C}_{\text {org }}$ values when compared to the OC-poor facies, 2) an increase in the inorganic productivity proxy $\mathrm{Ba} / \mathrm{Al}$ and, 3) $\mathrm{Ba}$ values in OC-rich facies are higher than those for OC-rich facies (except samples at $7.84,9.14$ and $10.31 \mathrm{~cm}), 4) \mathrm{Ba}$ values are variable (231 to $758 \mathrm{ppm}$ ) though are comparable to values recorded in modern upwelling systems e.g. Peru margin and Baja, California (see Table 3) but less than values from euxinic basins e.g. Black Sea (1171 ppm Brumsack, 2006). 
These patterns may suggest an increased productivity signal at the appearance of LH, however, because Ba values can be obscured by either euxinic conditions (Brumsack, 2006) or diagenesis (Milodowski and Zalasiewicz, 1991), it is possible our signal is obscured. We are only concerned with changes in productivity at the transition from OC-poor to OC-rich facies because this boundary represents a definite change in OC-burial and/or productivity. Our trace fossil redox data suggest that euxinic conditions were not achieved until after $1.8 \mathrm{~m}$ across the OC-poor - OC-rich boundary. Therefore Ba can be considered reliable up until this point in terms of diagenesis. This is seen on Fig. 5 where Ba values decrease $2 \mathrm{~m}$ into the $\mathrm{OC}$-rich event when conditions become euxinic and subsequently increase dramatically at the OC-rich to OC-poor boundary, possibly reflecting a 'barite-front' (Arndt et al., 2006; Brumsack, 2006).

Our bulk $\delta^{13} \mathrm{C}_{\text {org }}$ data show LH units contain more negative $\delta^{13} \mathrm{C}_{\text {org }}$ values than the OC-poor units. We consider this is not attributable to change in redox because sedimentary data and experimental data demonstrate greater depletion of ${ }^{13} \mathrm{C}_{\text {org }}$ in aerobic environments (Lehmann et al., 2002). The difference in carbon isotope depletion between diagenesis in an aerobic and anaerobic environment is only 0.16 per mil ( -1.81 per mil and -1.65 per mil respectively, Lehmann et al., 2002). The selective loss of different compounds with different reactivities and ${ }^{13} \mathrm{C}$ values during decay can account for minor shifts in the ${ }^{13} \mathrm{C}_{\text {org }}$ of marine sediments (Freeman, 2001). However, for algal-dominated organic matter, such as in the Ordovician oceans, this effect is less than 1 per mil (Freeman, 2001). Our values are greater than that expected from a change in redox environment and from loss of different compounds during diagenesis but consistent with increased burial of ${ }^{12} \mathrm{C}$-enriched carbon. Also, the appearance of OC-rich $\mathrm{LH}$ is coincident with a decrease in $\delta^{13} \mathrm{C}_{\text {org }}$ and not with the change in redox indicated by the trace fossils.

\section{$6 \quad$ Stability of trace metal proxies}

Both the values and patterns of $\mathrm{Ni}$ do not correspond to the sequence of redox conditions shown by the trace fossils. Indeed, during the deposition of the OC-rich facies, $\mathrm{Ni} / \mathrm{Co}$ values are indicative of fully oxic conditions and during OC-poor they indicate dysoxia (Table 4). We therefore conclude Ni and Co concentrations have been altered during late diagenesis to low-grade metamorphism and that none of the currently widely used trace element redox proxies can be used in low grade metamorphic rocks.

On the other hand, we are confident of the reliability of our $\mathrm{Ba}$ values as a productivity proxy because of its enrichment in the OC-rich facies relative to the Rare Earth elements (REE, La-Yb). The REE have been demonstrated to be mobile between turbidite beds and anoxic hemipelagites (Milodowski and 
Zalasiewicz, 1991) but REE in the OC-rich facies of our measured transect are not enriched or depleted relative to OC-poor facies (Figure 9) indicating either no remobilization or equal loss/gain of REE in each facies.

\section{A mid-palaeolatitude upwelling model for the upper Katian}

In upwelling systems ${ }^{12} \mathrm{C}$-enriched $\mathrm{CO}_{2}$ derived from ${ }^{13} \mathrm{C}$-depleted recycled organic matter is continually replaced from depth, therefore the supply of ${ }^{12} \mathrm{C}$ is effectively limitless in an open system that has high OC preservation such as an ocean with permanent deep water anoxia (Leggett, 1980). Where ${ }^{13} \mathrm{C}$ depleted $\left({ }^{12} \mathrm{C}\right.$-enriched) waters are brought up to the surface, as by upwelling, then ${ }^{13} \mathrm{C}$ values of surface waters are correspondingly lowered (Peeters et al., 2002; Pancost et al., 1999). Because particulate organic carbon (POC) $\delta^{13} \mathrm{C}_{\text {org }}$ values are apparently preserved in the underlying sediments (Pancost et al., 1999), $\delta^{13} \mathrm{C}_{\text {org }}$ values of sediment in upwelling areas will reflect a mixture of sources similar to that of suspended materials (Pancost et al., 1999). Further to this, in modern lacustrine (e.g. Hollander and McKenzie (1991)) and marine environments (e.g. Freeman and Hayes, 1992; Goericke, 1994; Goericke et al., 1994; Hofmann et al., 2000), $\delta^{13} \mathrm{C}_{\text {org }}$ has been shown to decrease as the concentration of dissolved $\mathrm{CO}_{2}\left[\mathrm{CO}_{2 a q}\right]$ in surface waters increases and as productivity increases. It therefore seems likely that $\delta^{13} \mathrm{C}_{\text {org }}$ in the current setting may be regarded as a proxy for upwelling intensity just as Pancost et al. (1999) recognized for organic carbon the Peruvian upwelling system. Finally, as recognised by Cave (1965), the presence of phosphate nodules throughout the succession in both OC-rich and OC-poor sediments is a further indication of nutrient-rich upwelling and the stabilisation of the redox boundary (Ingall et al., 1993, see also). Phosphorites have a limited occurrence at the present day, in particular being confined to zones of upwelling along west-facing continental margins (e.g. of Peru and S. Africa).

The LH units thus represent periods of higher productivity with increased organic carbon flux to the seafloor. The amount of marine organic carbon produced in the photic zone in the modern oceans is dependent largely on nutrient availability in surface waters (Berger et al., 1989; Jahnke, 1990). We suggest coastal upwelling continually recycled bio-limiting nutrients $(\mathrm{P}$, $\mathrm{Ba}$ ) from depth and ${ }^{12} \mathrm{C}$-enriched $\mathrm{CO}_{2 a q}$. Our elevated Ba levels and negative $\delta^{13} \mathrm{C}_{\text {org }}$ values for the OC-rich facies are therefore considered indicative of upwelling (Fig. $10 \mathrm{a}, \mathrm{c}$ ). During these periods of high productivity, increased oxidative respiration of organic matter resulted in; 1) the seafloor becoming increasingly oxygen depleted and, 2) an upwards expansion of the OMZ. Organic-poor shales were deposited during periods of decreased productivity and organic carbon flux and a return to more oxygenated seafloor ensued (Fig. $10 \mathrm{~b})$. 
Coastal upwelling intensity can vary with a number of factors, but the most important of these is the strength of the offshore winds (Hay and Brock, 1992). During the Late Katian, the Welsh Basin was located beneath the zone of southwesterly prevailing trade winds on a northwestwards facing coast (Fig. 11). We suggest that the cyclic nature of black shales in the Red Vein reflects the changing intensity of the upwelling system in response to the changing strength of the offshore trade winds as originally proposed by Cave (1965). During the Plio-Pleistocene the position and intensity of the trade winds varies with changes in ice volume and solar insolation respectively (Rind, 1998; Ruddiman, 2000). The intensification of coastal upwelling in the Welsh Basin and wider Iapetus Ocean prior to the Hirnantian glacial maximum may therefore reflect an increase in the size of the Hirnantian ice sheet. Subsequent shortterm cyclic patterns of increased upwelling $\left(\mathrm{LH}^{0}-\mathrm{LH}^{3}\right)$ could reflect orbitallymoderated changes in solar insolation and ice volume.

\section{Alternative models}

Controversy continues in regard of the origin of both modern and ancient OC-rich sediments. In the former this controversy is centred on the relative importance of primary productivity (OC flux) versus preservation. Here we review our interpretation of upwelling with respect to other possible mechanisms that could have produced a similar anoxic response in the Welsh Basin, namely the Runoff model and the Transgressive black shale model.

\subsection{The Runoff model and salinity stratification}

Weathering regime proxies $(\mathrm{K} / \mathrm{Al}, \mathrm{Ti} / \mathrm{Al})$ have recently demonstrated that fresh-water and detrital input into basins is important for the formation of oxygen minima and the burial of carbon e.g. the Cretaceous Ivorian Basin (Beckmann et al., 2005; Bjerrum et al., 2006; Sobarzo et al., 2007). Along the upwelling margin of Chile, high freshwater input suppresses upwelling through the formation of a salinity stratified layer during wetter periods resulting in lower oxygen values at depth (Sobarzo et al., 2007). Higher $\mathrm{K} / \mathrm{Al}$ values and constant $\mathrm{Ti} / \mathrm{Al}$ values during OC-rich deposition indicates Avalonia was experiencing more arid weathering conditions at this time with less fluvial input, precluding the means to produce a salinity-stratified basin from increased continental freshwater runoff.

The lower $\mathrm{K} / \mathrm{Al}$ values found in $\mathrm{OC}$-poor facies indicate a more humid climate with higher fluvial input but not significant to develop salinity stratification. As the majority of the Late Katian Welsh Basin deposits are represented 
by the OC-poor burrow-mottled facies, we propose a stable humid climate prevailed for much of the Late Katian prior to the deposition of the Red Vein.

\subsection{The Transgressive black shale model}

The OC-rich units may correspond to a period of relative high sea-level during the anceps Biozone, the Husbergøya drowning event (Nielsen, 2004), but we do not consider a mechanism associated with transgression to be the cause for black shale formation in the Welsh Basin. The transgressive black shale model of Page et al. (2007) is essentially a glacioeustatic variant of the Runoff model, i.e. high nutrient input and productivity from glacial meltwater with associated sea-level rise. The stability of our $\mathrm{Ti} / \mathrm{Al}$ ratio data throughout the OC-poor-LH-OC-poor transitions preclude increased runoff as previously mentioned. An alternative transgressive black shale model, the 'Expanding puddle model' (Wignall, 1991) involves expansion of the OMZ as sea-level rises and may be suitable considering the Palaeozoic oceans were predisposed to permanent anoxia (Leggett, 1980). However, sea-level rise alone would only expand the OMZ and raise the pycnocline if accompanied by increased productivity and oxidation of organic matter which is not implicit from sea-level rise alone.

Furthermore, an influence of global sea-level rise on the Welsh Basin during the anceps Biozone has not been demonstrated, however, a sequence stratigraphical study has been undertaken for the lower Palaeozoic of the Welsh Basin (Woodcock, 1990) but it was not conducted at a resolution that would determine eustatic rise or fall for the individual OC-rich units. Woodcock (1990) did demonstrate a sequence boundary during the upper Katian corresponding to the uppermost Pusgillian (British Stages) but one controlled by local tectonism rather than global eustasy. There are also further fundamental complications for reconstructing high resolution intra-basinal sequence stratigraphy from sediments in distal basin settings alone. In the Welsh Basin setting, background hemipelagite sedimentation is interrupted by mm-thick silt to sand-sized turbiditic event beds. Unless the frequency and/or magnitude of the coarse-grained turbiditic component can be demonstrated to be of climatic origin e.g. possessing cyclicity corresponding to known climaticallydriven processes, interpreting changes in coarse-grained sediment flux between OC-poor and LH units as a product of sea-level rise or fall is speculative.

\section{Conclusions}

The fine grained siliciclastic rocks of the Welsh Basin record an evolving sequence of events during the transition from Ordovician greenhouse to icehouse 
climate states. We postulate that the proxy records presented herein indicate short-lived, cyclic enhanced upwelling and surface organic productivity along the southern Iapetus margin. Increased upwelling and productivity was induced by increased wind stress from intensification of coast-parallel to offshore SE trade winds. Higher productivity and OC supply to the deep ocean resulted in a rise in the position of the OMZ, which breached the semi-restricted Welsh Basin, in response to increased oxygen depletion of the water column. Black shale deposition was controlled by complex climate-ocean-biosphere interactions likely reflecting responses to ice volume changes during the developing end Ordovician glaciation. Metamorphism to anchizone metamorphic facies reduces the number of ocean-environment proxies that can be a used to elucidate palaeoenvironmental conditions. We consider the productivity proxies, $\mathrm{Ba} / \mathrm{Al}$, TOC $\%, \delta{ }^{13} \mathrm{C}_{\text {org }}$ and the climate-sensitive detrital input proxies $\mathrm{K} / \mathrm{Al}$ and $\mathrm{Ti} / \mathrm{Al}$ to be robust and could be widely applied in the slate grade rocks commonly found in orogenic belts. 
Figure 1. Stratigraphic chart (a) showing the correlation between the sections at Dob's Linn (International boundary stratotype fro the base of the Silurian System), after Underwood et al. (1997). (b) Palaeogeographic map of the Iapetus Ocean during the Upper Ordovician (based on Hermann et al. (2005)). This shows the distribution of the major continental land masses (L = Laurentia, $\mathrm{S}=$ Siberia, $\mathrm{B}=$ Baltica, $\mathrm{A}=$ Avalonia) and major surface currents (solid arrows).

Figure 2. Regional Geology of the Laye Katian of the Cardigan-Llangranog region, southwest Wales, UK. Abbreviations on regional location map BW $=$ Builth Wells, $\mathrm{CI}=$ Cadair Idris, LL = Llangranog, $\mathrm{NE}=$ Newcastle Emlyn, Rhay = Rhayader. Chronostratigraphy from Fortey et al. (2000) and Webby et al. (2004), chitinozoan biozonation from Vandenbroucke and Vanmeirhaeghe (2007), graptolite biozonation and Time slices from Webby et al. (2004), lithostratigraphy from Davies et al. (2003).

Figure 3. Composite stratigraphical chart showing variations in $\delta^{13} \mathrm{C}_{\text {org }}$ and TOC \% profile throughout upper Katian (Cautleyan-Rawtheyan, Upper Ordovician) of the Cardigan-Penbryn coastal section, Welsh Basin (SN 161500 to SN 296-530)

Figure 4. Ichnofaunal responses to organic-rich sedimentation and development of anoxia at OC-rich unit $\mathrm{LH}^{0}$, Aberporth. See text for details of sampling location.

Figure 5. Geochemical proxy data plotted against stratigraphical height above base of $\mathrm{LH}^{1}$, Traeth Penbryn. Error bars represent 1- $\sigma$.

Figure 6. Cross-plots for a) TOC $\%$ vs. $\delta^{13} \mathrm{C}_{\text {org }}$, b) Ba vs. $\mathrm{Al}$ and c) $\mathrm{Ba} / \mathrm{Al}$ vs. TOC $\%$.

Figure 7. Cross-plots for a) Co vs. $\mathrm{Ni}$, b) $\mathrm{Ni}$ vs $\mathrm{Al}$ and c) $\mathrm{Ni} / \mathrm{Al}$ vs. TOC $\%$

Figure 8. Infaunal biofacies model of (Arthur and Sageman, 1994). level 1 reflects anaerobic conditions both above and below the SWI, with laminated sediments, the highest levels of preserved TOC and no evidence of benthic metazoans. At level 2 micro-burrowing disturbs the sedimentary laminae. Level 3 includes small deposit feeding pioneer ichnotaxa such as Chondrites or Planolites. Level 4 is characterized by an increase in the size and density of Planolites and Chondrites burrows, but no additional ichnotaxa. At level 5 more complex feeding traces such as Zoophycos and Teichichnus are found. Level 6 is indicated by the appearance of sediment-dwelling ichnotaxa ("domichnia") such as Thalassinoides. Above level 6 all groups included produce high-diversity assemblages. The Chondrites, Planolites and Thalassinoides ichnocoenoses present in the OC-poor sediments and the transition to OC-rich sediments represent infaunal biofacies levels 3-4. Interpreted oxygen 
levels at base of diagram (also from Arthur and Sageman, 1994) correspond to biofacies as shown.

Figure 9. Light, middle and heavy Rare Earth Elements (La, Sm, Yb) plotted against stratigraphical height above base of $\mathrm{LH}^{1}$, Traeth Penbryn. Sample points are scaled to maximum error.

Figure 10. Summary of all proxies during deposition of LH (a) Together, all proxies demonstrate that upwelling and oxygen deterioration commenced prior to the deposition of each LH event. Falling oxygen conditions were relatively gradual until euxinia was established whilst oxygen recovery was rapid yet fluctuated and occurred prior to the cessation of LH deposition. (b) Low productivity conditions were typified by weak upwelling and a depressed OMZ whereas high producitivity conditions (c) occurred during high wind stress and increased upwelling that recycled nutrients and ${ }^{12} \mathrm{C}$-enriched OC. $\mathrm{ML}=$ mixed layer.

Figure 11. Inferred trade wind positions and directions (from Parrish (1982)) over Avalonia. Palaeogeography adapted from Hermann et al. (2004). 
Table 1. Reproducibility and error data for all shale ICP-MS runs using shale standard SGR-1. Each run included both OC-rich and OC-poor samples. Al, $\mathrm{K}, \mathrm{Ti}$ and $\mathrm{Mn}$ in wt\% oxide, all other elements in ppm.

Table 2. $f$ - and $t$-test statistics for $\mathrm{Ba} / \mathrm{Al}$ and $\mathrm{Ba}(\mathrm{ppm})$ through $\mathrm{LH}^{1}$, Traeth Penbryn. Both the means and variances for $\mathrm{Ba} / \mathrm{Al}$ and $\mathrm{Ba}(\mathrm{ppm})$ are significantly different at $\alpha=0.05$ between OC-poor and OC-rich units.

Table 3. Trace metal values for modern and Welsh Ordovician OC-rich black shales. $\mathrm{Al}, \mathrm{K}, \mathrm{Ti}$ and $\mathrm{Mn}$ in wt\% oxide, all other elements in ppm. ${ }^{1}$ Boening et al. (2004), ${ }^{2}$ Borchers et al. (2005), ${ }^{3}$ Brunsack (1989), ${ }^{4}$ Warnnig and Brumsack (2000), ${ }^{5}$ Temple and Cave (1992), ${ }^{6}$ McCann (1990), ${ }^{7}$ Brumsack (2006).

Table 4. End-member values for trace element ratios for depositional redox conditions, Ni/Co. ${ }^{1}$ (Jones and Manning, 1994) 


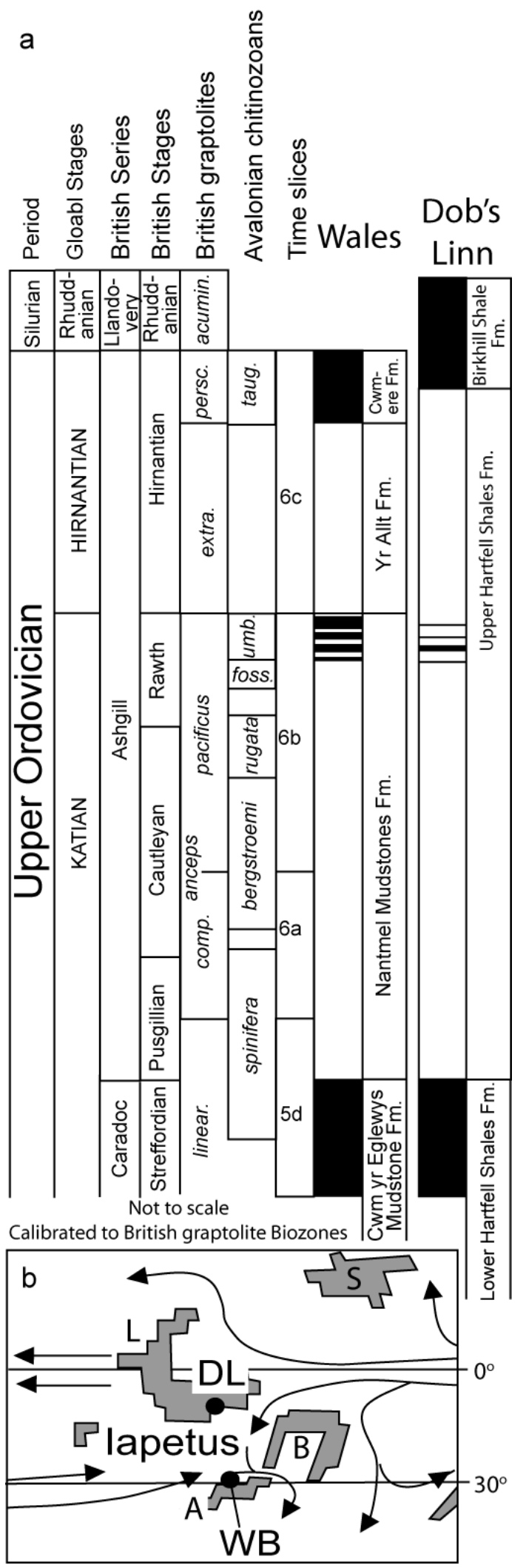

Fig. 1. 

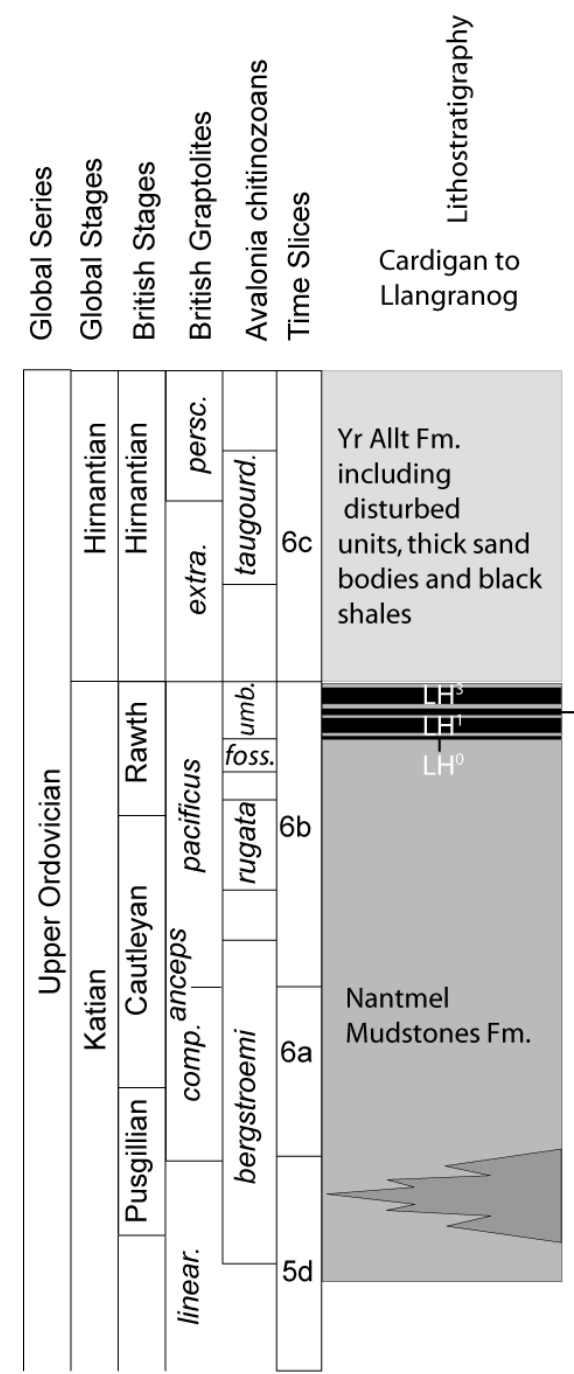

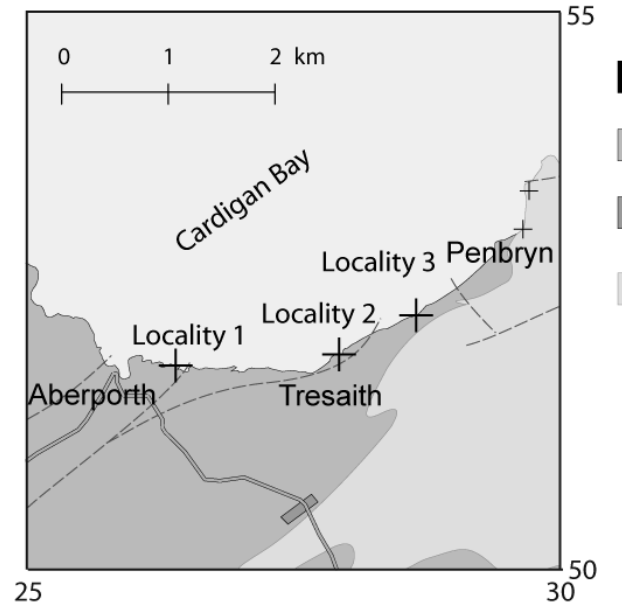

$\mathrm{H}^{2}$ Red Vein

Assemblage

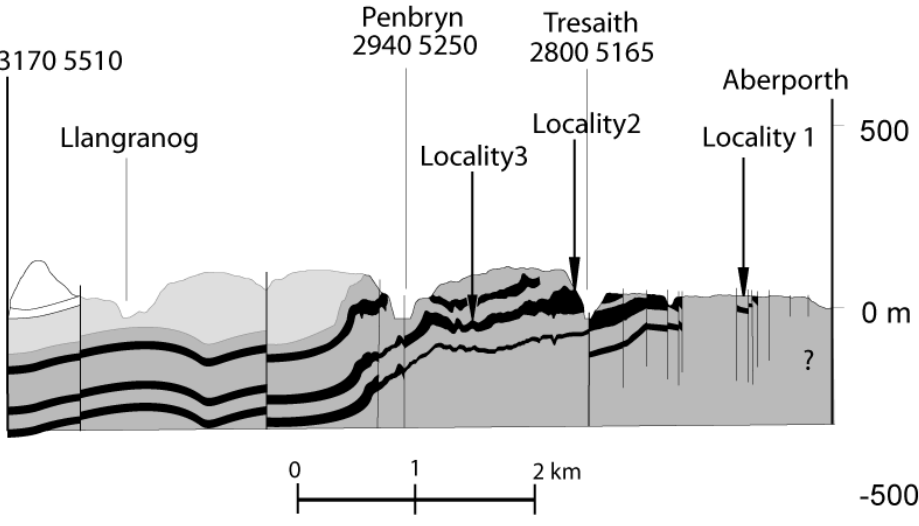

Fig. 2.
Organic-rich laminated hemipelagite (Nantmel Mudstones Formation)

Nantmel Mudstones Formation

Sandy facies

(Nantmel Mudstones Formation)

Yr Allt Fomation

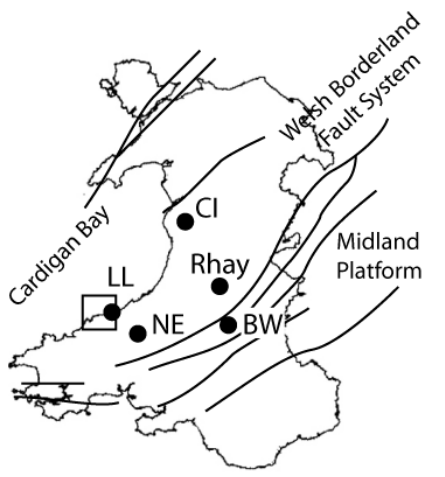

Aberporth

500

m 


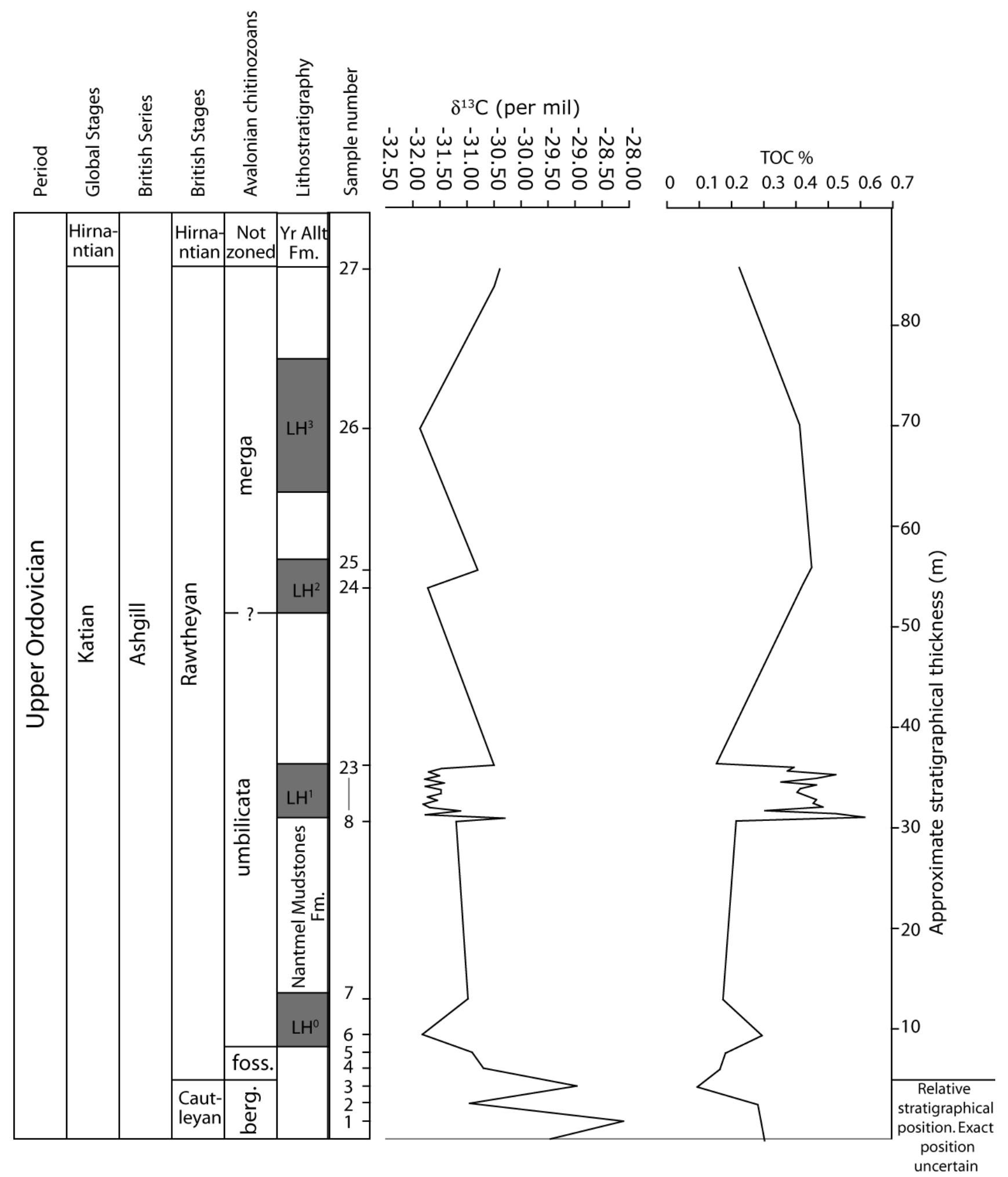

Fig. 3. 


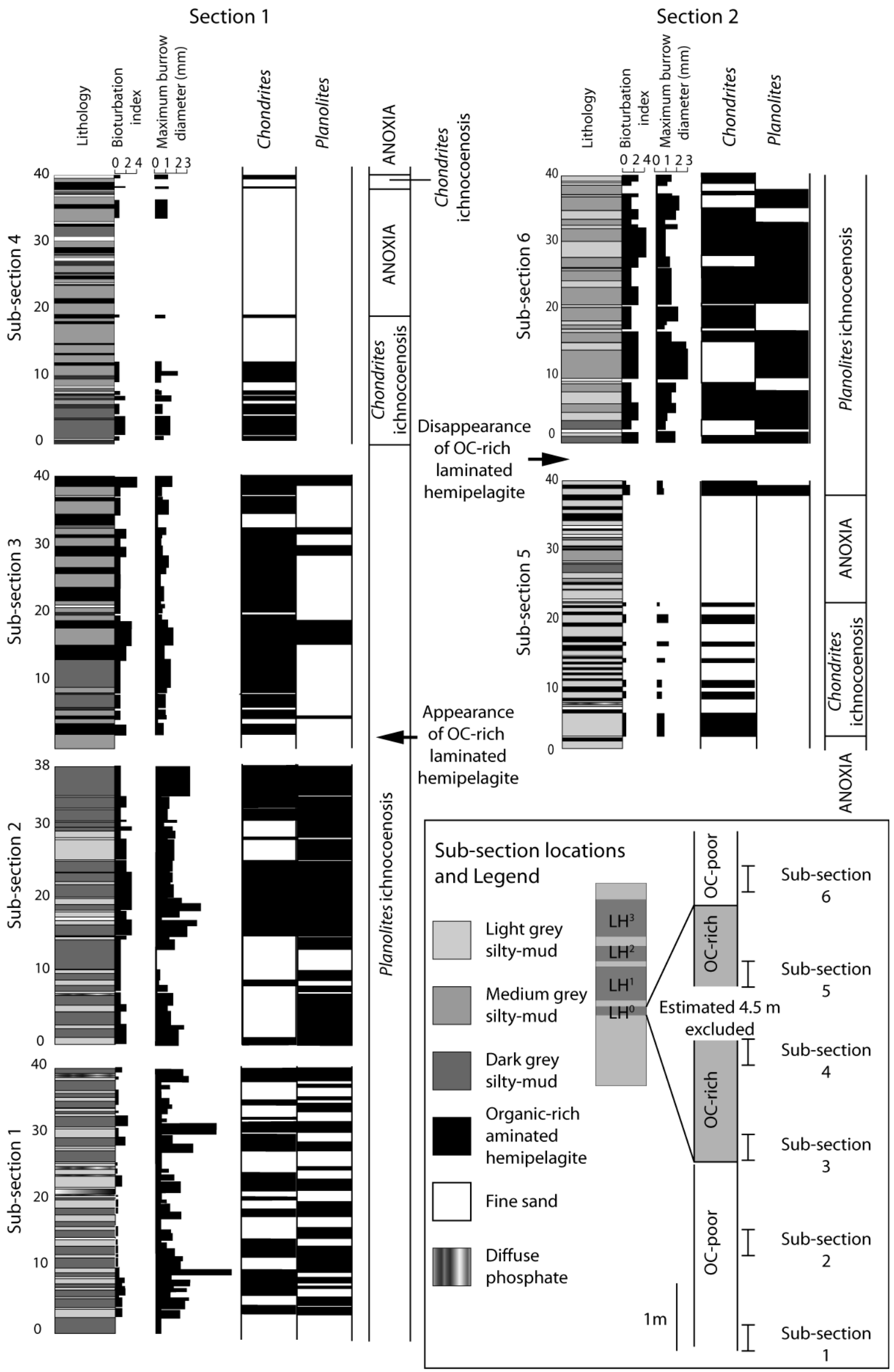

Fig. 4 


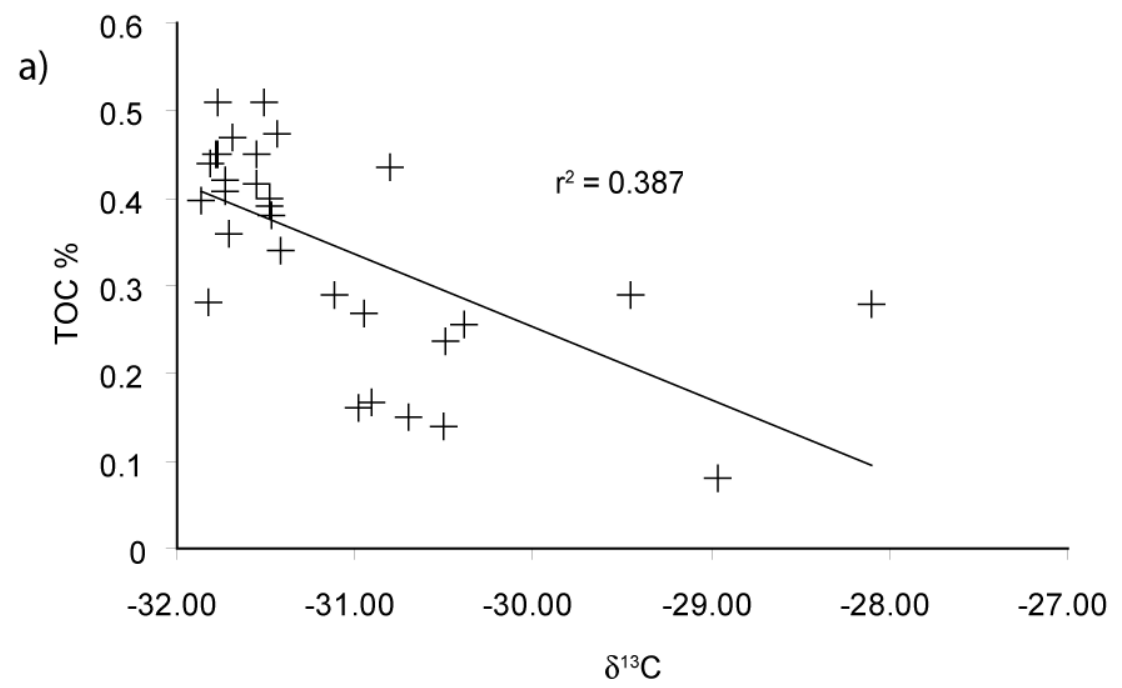

b)
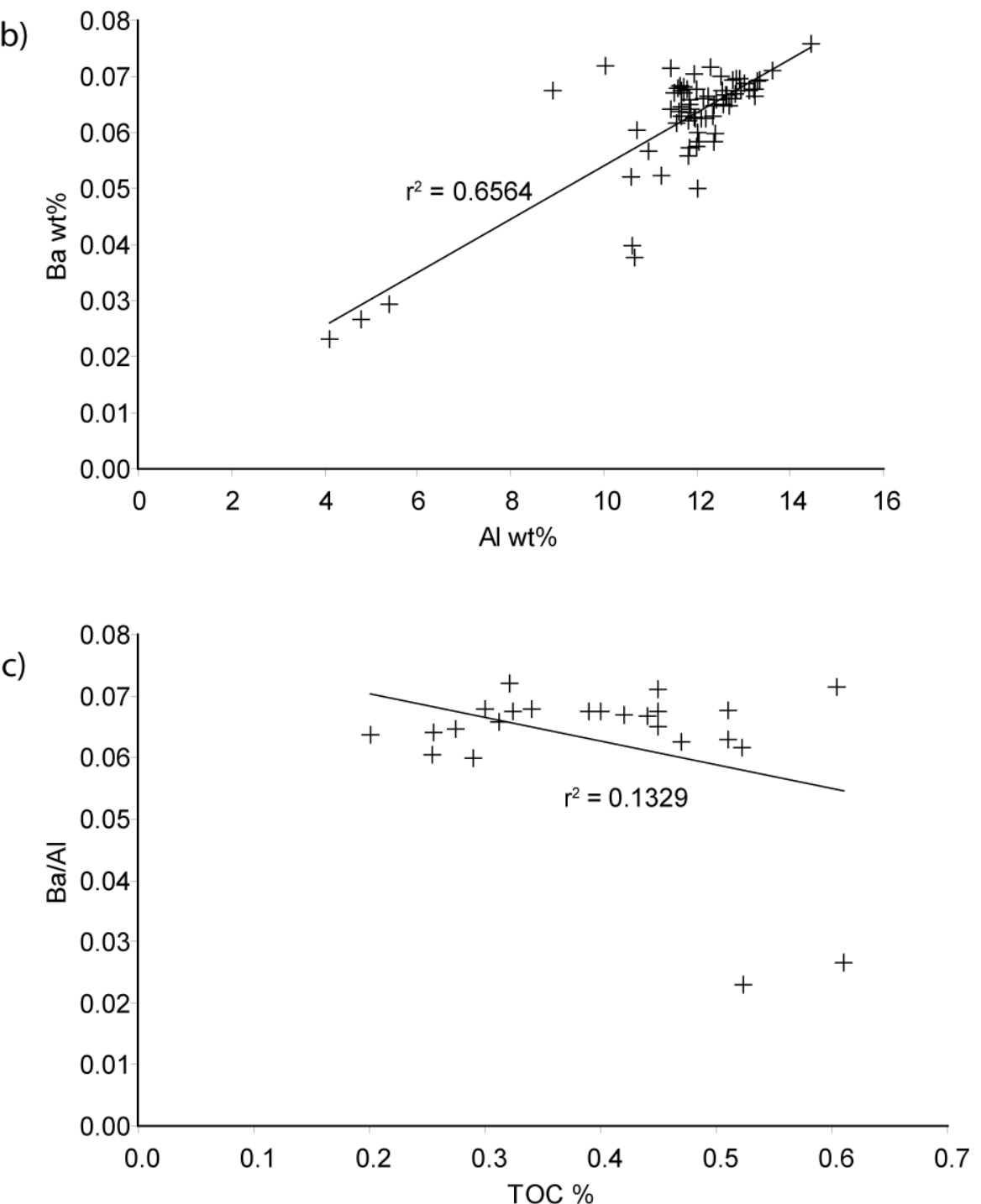

Fig. 6 . 

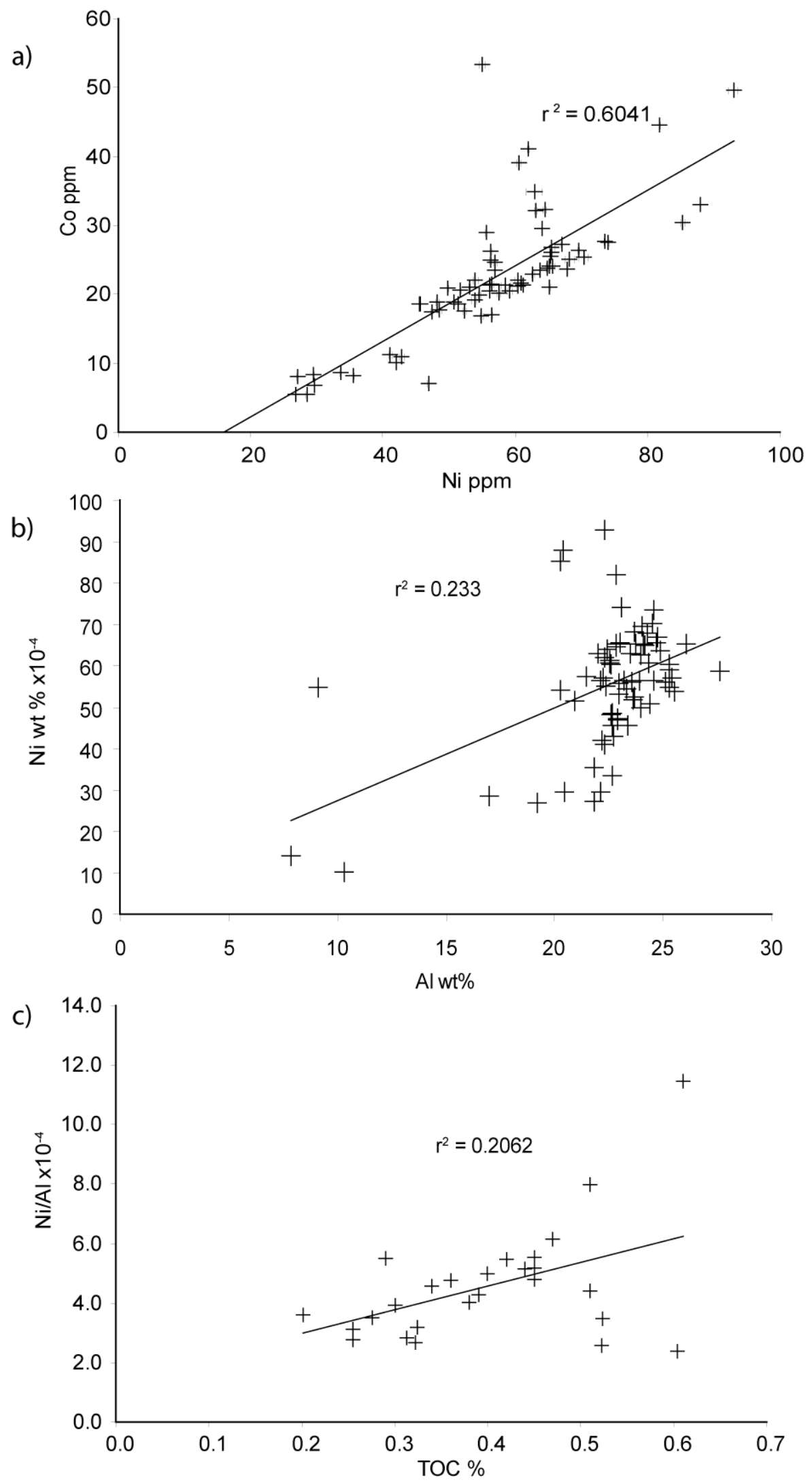

Fig. 7. 


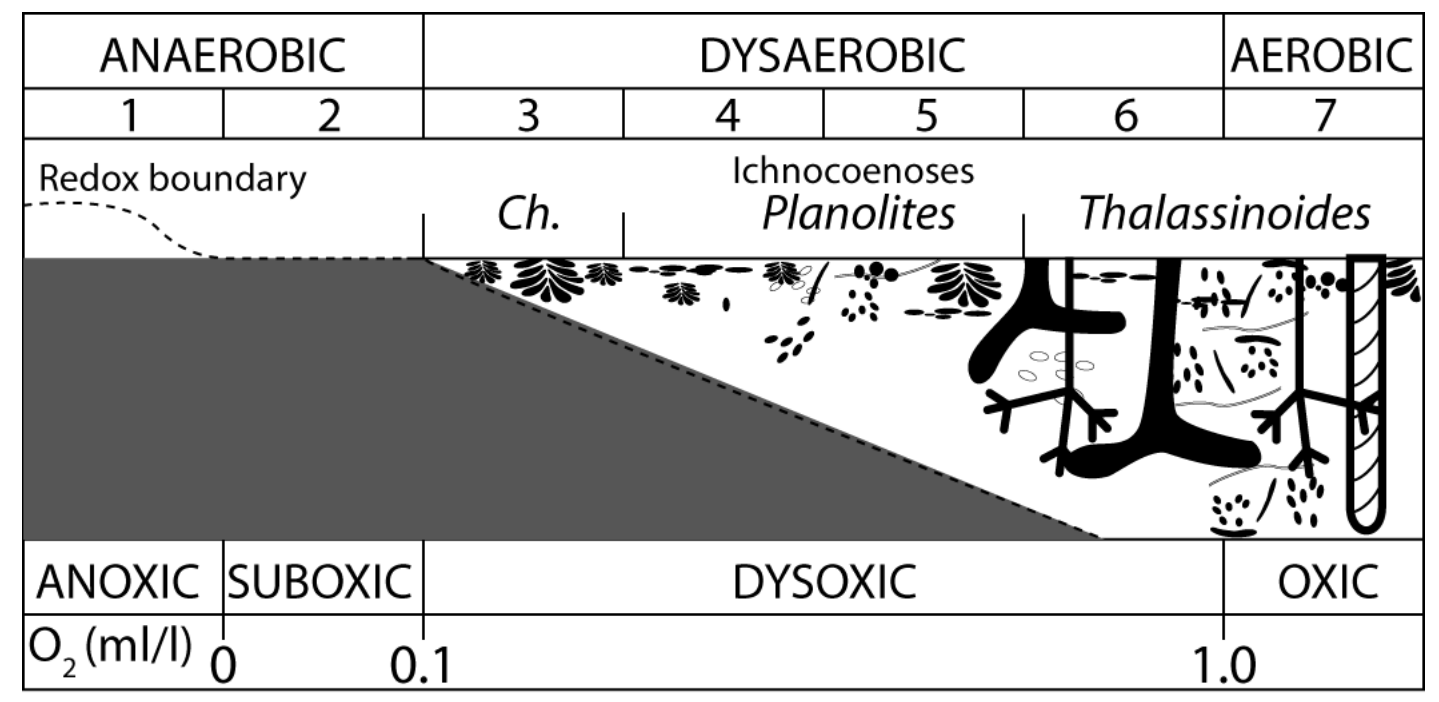

Fig. 8. 


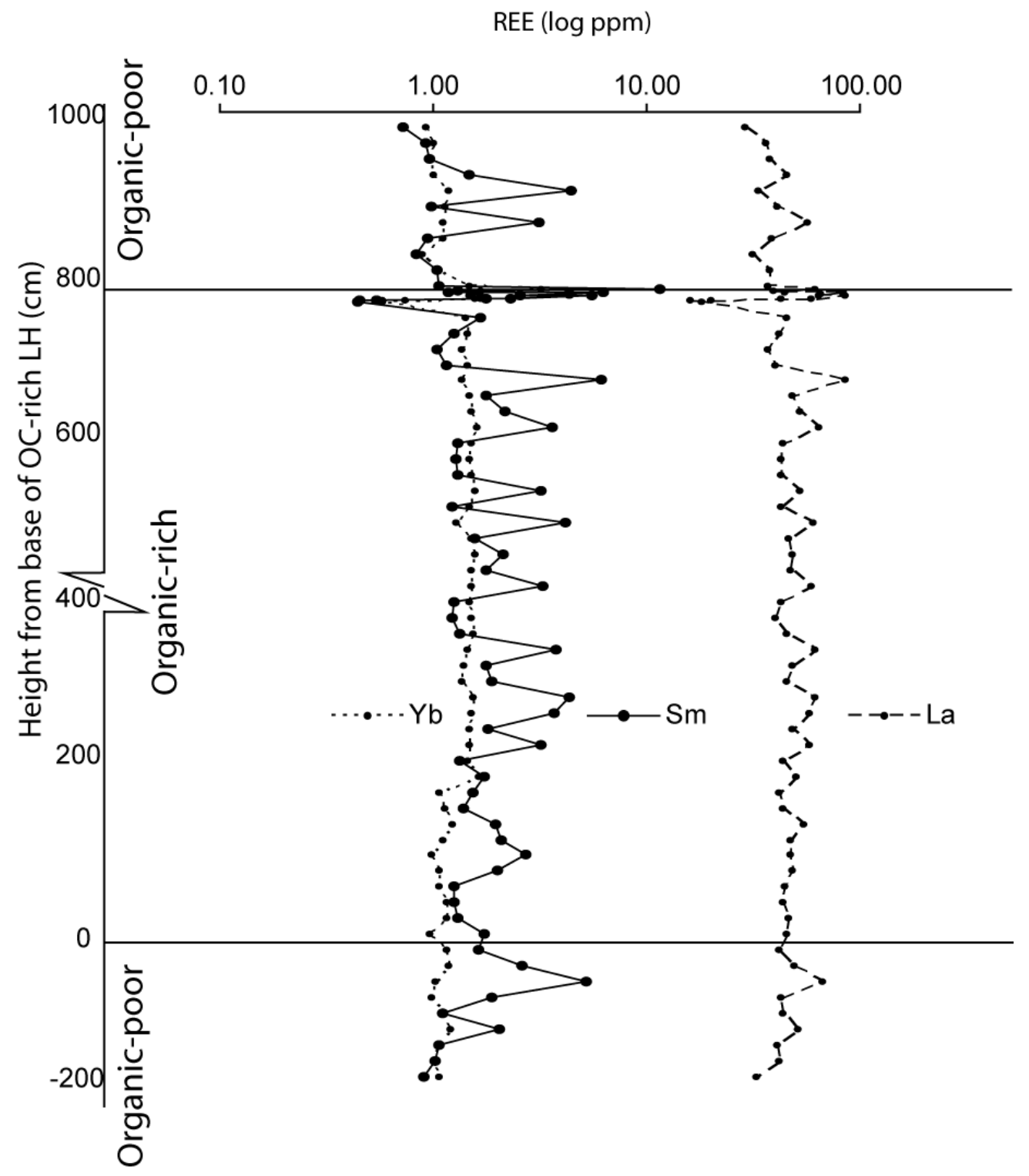

Fig. 9. 
a) Long term TOC and

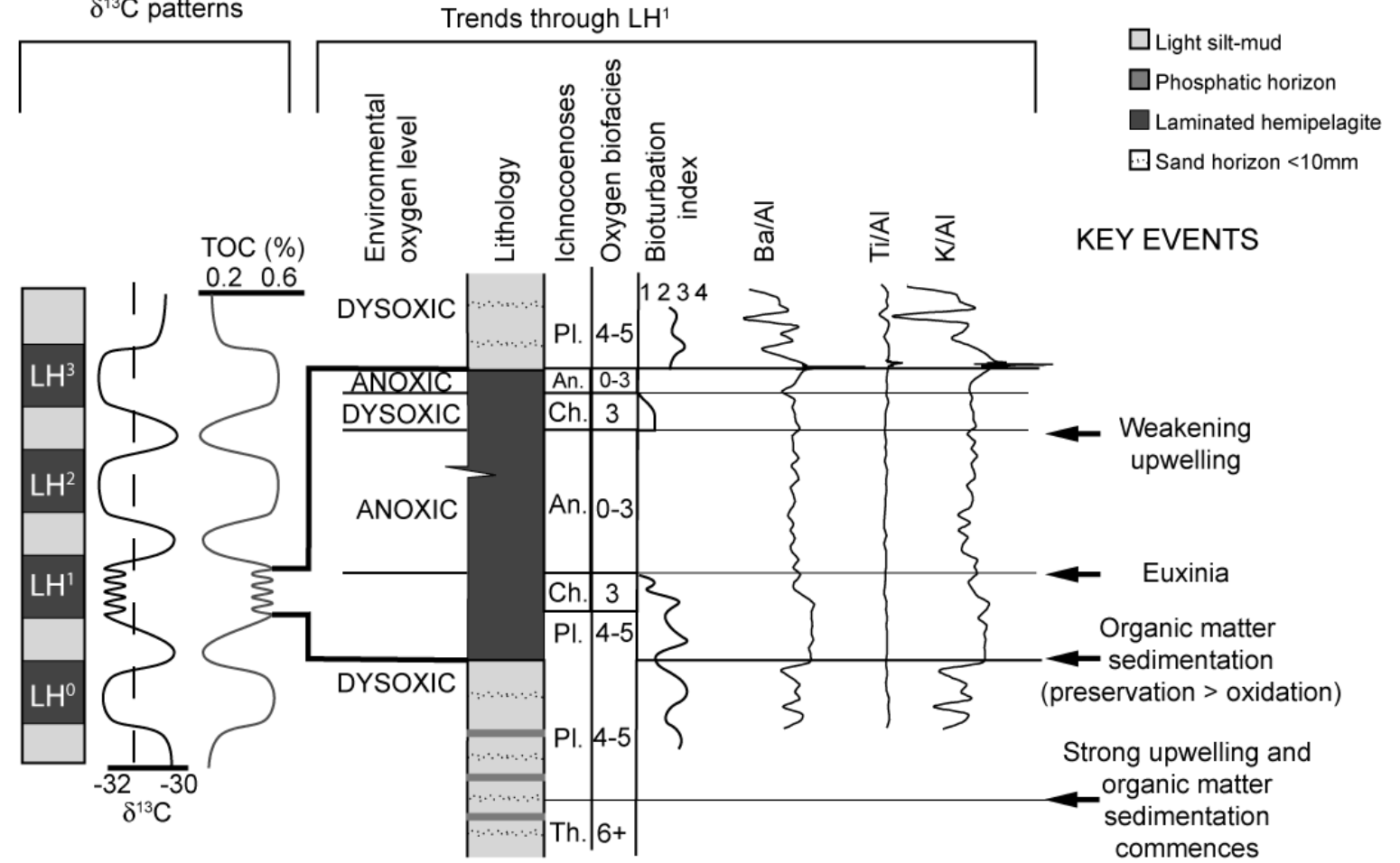

b)

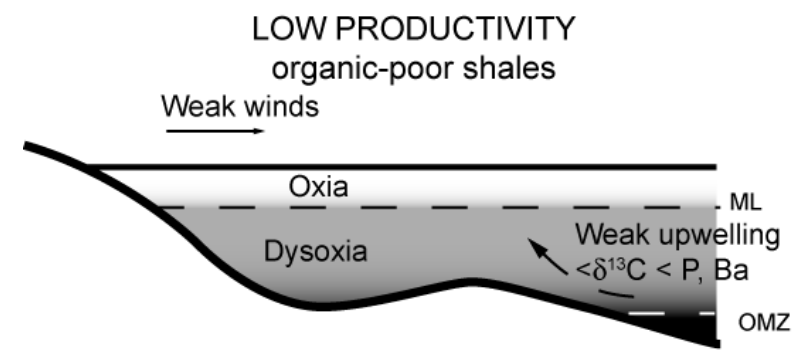

c)

HIGH PRODUCTIVITY

organic-rich shales

Intensified SE trade winds from temperate-arid climate

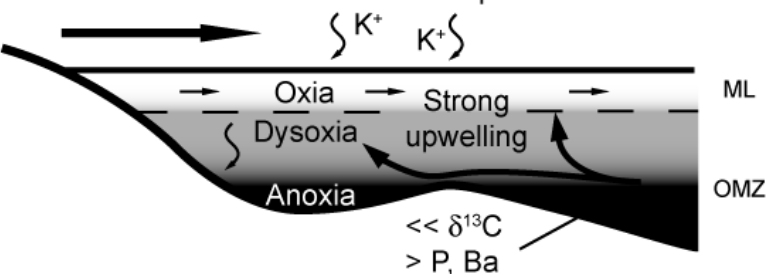

Fig. 10. 


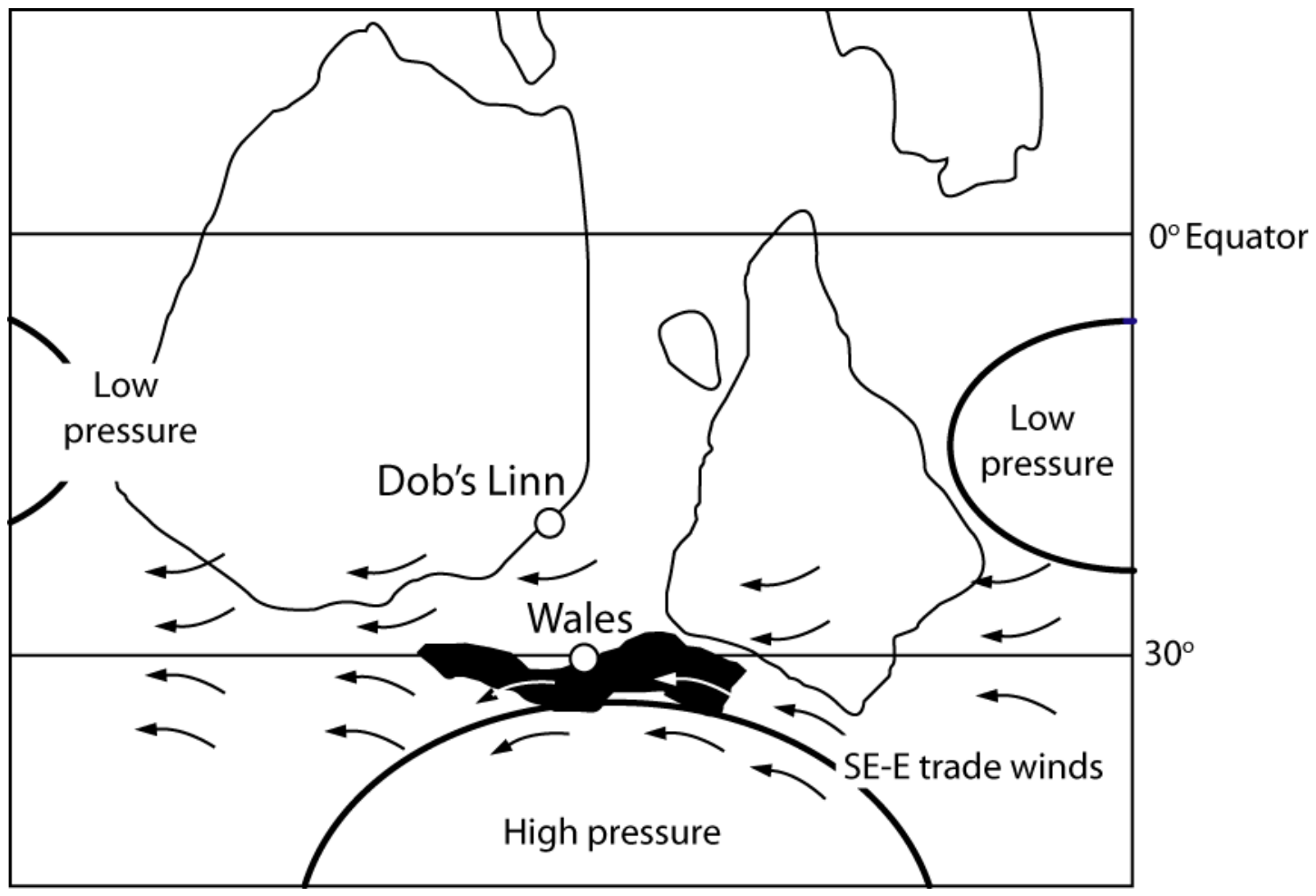

Fig. 11. 
Table 1

\begin{tabular}{llllllllll}
\hline \multicolumn{3}{l}{ Run-1, n=2 } & \multicolumn{3}{c}{ Run-2, n=7 } & \multicolumn{3}{c}{ Run-3, n-2 } \\
\hline & Mean & StDev & RSD $\%$ & Mean & StDev & RSD\% & Mean & StDev & RSD\% \\
\hline $\mathrm{Al}$ & 6.1 & 0.15 & 2.47 & 6.92 & 0.5 & 7.2 & 18.66 & 1.37 & 7.36 \\
$\mathrm{~K}$ & 1.57 & 0.03 & 1.71 & 1.63 & 0.07 & 4.48 & 2.24 & 0.0 & 0.22 \\
$\mathrm{Ti}$ & 0.24 & 0.01 & 3.85 & 0.24 & 0.01 & 2.60 & 0.26 & 0.02 & 7.18 \\
$\mathrm{~V}$ & 120.56 & 3.88 & 3.22 & 121.82 & 2.70 & 2.22 & 124.12 & 7.81 & 6.29 \\
$\mathrm{Cr}$ & 29.62 & 0.34 & 1.16 & 33.31 & 0.95 & 2.85 & 33.60 & 1.87 & 5.56 \\
$\mathrm{Mn}$ & 0.03 & 0.00 & 0.00 & 0.03 & 0.00 & 2.43 & 0.03 & 0.00 & 4.29 \\
$\mathrm{Co}$ & 11.35 & 0.29 & 2.52 & 11.87 & 0.19 & 1.63 & 12.39 & 0.39 & 3.12 \\
$\mathrm{Ni}$ & 25.69 & 0.52 & 2.01 & 31.10 & 0.70 & 2.25 & 31.62 & 1.23 & 3.90 \\
$\mathrm{Cu}$ & 60.60 & 0.44 & 0.72 & 60.73 & 0.53 & 0.87 & 63.84 & 1.91 & 3.00 \\
$\mathrm{Ba}$ & 299.63 & 1.89 & 0.63 & 295.20 & 8.16 & 2.77 & 263.07 & 8.72 & 3.32 \\
$\mathrm{Th}$ & 4.65 & 0.14 & 3.04 & 4.61 & 0.12 & 2.50 & 4.38 & 0.24 & 5.56 \\
$\mathrm{U}$ & 5.17 & 0.03 & 0.67 & 5.09 & 0.11 & 2.14 & 4.68 & 0.28 & 6.05 \\
\hline
\end{tabular}

Table 2

\begin{tabular}{c|cccc|cccc}
\hline & OC-poor & OC-rich & t-stat & t-crit & OC-poor & OC-rich & f-stat & f crit. \\
& Mean & Mean & & 2 -tail & Var. & Var. & 1-tail \\
\hline \hline $\mathrm{Ba} / \mathrm{Al}$ & $5.1 \times 10^{-} 3$ & $5.4 \times 10^{-} 3$ & -2.33 & \pm 2.03 & $3.55 \times 10^{-} 7$ & $7.31 \times 10^{-} 8$ & 4.85 & 1.76 \\
$\mathrm{Ba}(\mathrm{ppm})$ & 601.5 & 653.2 & -2.5 & \pm 2.0 & 6405.9 & 7978.3 & 0.8 & 0.55 \\
\hline
\end{tabular}




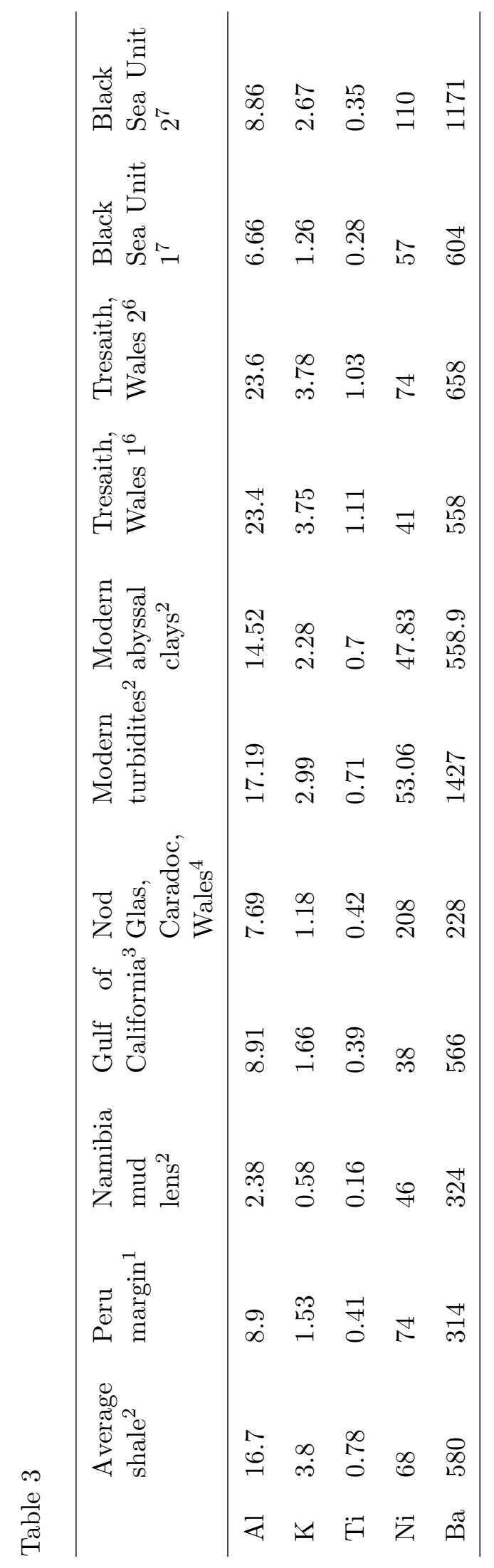


Table 4

\begin{tabular}{ccccc}
\hline & Oxic & Dysoxic & Suboxic-Anoxic & Euxinic \\
\hline $\mathrm{Ni} / \mathrm{Co}^{1}$ & $<5.00$ & $5.00-7.00$ & $>7.00$ & \\
\hline
\end{tabular}


Table 5

$\delta^{13} \mathrm{C}_{\text {org }}$ and TOC for Cardigan coast line, Ceredigion, Wales. Samples are listed from stratigraphically lowest (oldest) to highest (youngest).

\begin{tabular}{|c|c|c|c|}
\hline Sample no. & Locality & $\delta^{13} \mathrm{C}_{\text {org }}$ per mil & TOC $\%$ \\
\hline 1 & Gwbert Hotel (SN 161 500) & -29.46 & 0.29 \\
\hline 2 & Carreg Lydan (SN 162 513) & -28.1 & 0.28 \\
\hline 3 & Mwnt (SN 192 519) & -30.95 & 0.27 \\
\hline 4 & Pen-y-Craig (SN 218 523) & -28.97 & 0.08 \\
\hline 5 & Aberporth (SN 258 515) & -30.70 & 0.15 \\
\hline 6 & $\mathrm{LH}^{0}$ lower boundary, subsection 3 (SN 625515$)$ & -30.91 & 0.17 \\
\hline 6 & $\mathrm{LH}^{0} 2 \mathrm{~m}$, subsection 3 (SN 625515$)$ & -31.83 & 0.28 \\
\hline 7 & $\mathrm{LH}^{0}$ upper boundary, subsection 6 (SN 625515$)$ & -30.98 & 0.16 \\
\hline 8 & $\mathrm{LH}^{1}-80 \mathrm{~cm}$ from LH boundary, Tresaith (SN 280 516) & -31.2 & 0.38 \\
\hline 9 & $\mathrm{LH}^{1}-40 \mathrm{~cm}$ from LH boundary, Tresaith (SN 280516 ) & -30.3 & 0.36 \\
\hline 10 & $\mathrm{LH}^{1} 240 \mathrm{~cm}$ from LH boundary, Tresaith (SN 280 516) & -31.77 & - \\
\hline 11 & $\mathrm{LH}^{1} 280 \mathrm{~cm}$ from LH boundary, Tresaith (SN 280516 ) & -31.12 & - \\
\hline 12 & $\mathrm{LH}^{1} 320 \mathrm{~cm}$ from LH boundary, Tresaith (SN 280 516) & -31.69 & 0.51 \\
\hline 13 & $\mathrm{LH}^{1} 360 \mathrm{~cm}$ from LH boundary, Tresaith (SN 280516 ) & -31.81 & 0.45 \\
\hline 14 & $\mathrm{LH}^{1} 400 \mathrm{~cm}$ from LH boundary, Tresaith (SN 280516 ) & -31.55 & 0.34 \\
\hline 15 & $\mathrm{LH}^{1} 440 \mathrm{~cm}$ from LH boundary, Tresaith (SN 280 516) & -31.73 & 0.45 \\
\hline 16 & $\mathrm{LH}^{1} 480 \mathrm{~cm}$ from LH boundary, Tresaith (SN 280 516) & -31.48 & 0.40 \\
\hline 17 & $\mathrm{LH}^{1} 520 \mathrm{~cm}$ from LH boundary, Traeth Penbryn (SN 289 522) & -31.48 & 0.39 \\
\hline 18 & $\mathrm{LH}^{1} 560 \mathrm{~cm}$ from LH boundary, Traeth Penbryn (SN 289 522) & -31.77 & 0.42 \\
\hline 19 & LH ${ }^{1} 600 \mathrm{~cm}$ from LH boundary, Traeth Penbryn (SN 289 522) & -31.42 & 0.45 \\
\hline 20 & LH ${ }^{1} 640 \mathrm{~cm}$ from LH boundary, Traeth Penbryn (SN 289 522) & -31.78 & 0.44 \\
\hline 20 & LH ${ }^{1} 680 \mathrm{~cm}$ from LH boundary, Traeth Penbryn (SN 289 522) & -31.51 & 0.47 \\
\hline 21 & $\mathrm{LH}^{1} 720 \mathrm{~cm}$ from LH boundary, Traeth Penbryn (SN 289 522) & -31.71 & 0.29 \\
\hline 22 & LH ${ }^{1} 760 \mathrm{~cm}$ from LH boundary, Traeth Penbryn (SN 289 522) & -31.47 & 0.51 \\
\hline 23 & LH ${ }^{1} 800 \mathrm{~cm}$ from LH boundary, Traeth Penbryn (SN 289 522) & -30.50 & 0.20 \\
\hline 24 & $\mathrm{LH}^{2}(\mathrm{SN} 293523)$ & -31.73 & 0.41 \\
\hline 25 & $\mathrm{LH}^{3}$ lower boundary, org.-poor facies (SN 296528 ) & -30.8 & 0.44 \\
\hline 26 & $\mathrm{LH}^{3}$ lower boundary org.-rich facies (SN 296528 ) & -31.87 & 0.40 \\
\hline 27 & Highest Nantmel Mudstones Formation (SN 296 530) & -30.50 & 0.24 \\
\hline
\end{tabular}


Table 6: Trace element data, $\mathrm{LH}^{1}$, Traeth Penbryn. All depths from the base $\mathrm{LH}^{1}$. $\mathrm{Al}, \mathrm{K}, \mathrm{Ti}$ are recorded as wt $\%$ oxide, $\mathrm{Co}, \mathrm{Ni}$ and $\mathrm{Ba}$ are recorded as ppm.

\begin{tabular}{|c|c|c|c|c|c|c|}
\hline $\begin{array}{l}\text { Depth } \\
(\mathrm{cm})\end{array}$ & $\mathrm{Al}$ & $\mathrm{K}$ & $\mathrm{Ti}$ & Co & $\mathrm{Ni}$ & $\mathrm{Ba}$ \\
\hline-200 & 20.30 & 2.55 & 0.78 & 30.38 & 85.26 & 398.42 \\
\hline-180 & 21.48 & 3.30 & 0.97 & 20.15 & 57.48 & 523.08 \\
\hline-160 & 22.57 & 3.54 & 1.00 & 21.41 & 61.18 & 558.80 \\
\hline-140 & 22.95 & 3.78 & 1.02 & 21.08 & 53.14 & 599.76 \\
\hline-120 & 20.38 & 2.37 & 0.72 & 33.00 & 87.89 & 376.33 \\
\hline-100 & 22.70 & 3.65 & 1.05 & 11.00 & 42.86 & 635.11 \\
\hline-80 & 22.90 & 3.64 & 1.04 & 17.49 & 47.34 & 575.91 \\
\hline-60 & 20.94 & 3.18 & 0.86 & 18.60 & 51.35 & 566.61 \\
\hline-40 & 22.98 & 3.74 & 1.05 & 28.99 & 55.59 & 500.10 \\
\hline-20 & 23.62 & 4.05 & 1.10 & 20.63 & 51.74 & 582.61 \\
\hline 0 & 22.20 & 3.93 & 1.01 & 10.03 & 42.02 & 636.98 \\
\hline 5.5 & 20.46 & 3.77 & 0.90 & 8.31 & 29.55 & 603.73 \\
\hline 6.5 & 22.31 & 3.87 & 1.08 & 11.18 & 41.09 & 645.21 \\
\hline 8 & 22.91 & 4.14 & 1.11 & 7.00 & 46.88 & 677.80 \\
\hline 9.5 & 22.65 & 3.79 & 1.03 & 8.59 & 33.52 & 658.14 \\
\hline 10.25 & 21.86 & 3.62 & 0.99 & 8.18 & 35.54 & 641.16 \\
\hline 11.75 & 17.02 & 3.60 & 1.07 & 5.48 & 28.45 & 674.28 \\
\hline 13.5 & 19.19 & 3.40 & 1.01 & 5.47 & 26.77 & 719.64 \\
\hline 16 & 21.85 & 3.71 & 1.08 & 8.01 & 27.05 & 713.92 \\
\hline 17 & 22.11 & 4.06 & 1.10 & 6.80 & 29.65 & 615.95 \\
\hline 18 & 10.31 & 1.90 & 0.53 & 5.85 & 10.32 & 293.64 \\
\hline 19.25 & 7.84 & 1.41 & 0.40 & 9.41 & 14.24 & 230.62 \\
\hline 20.5 & 9.14 & 1.60 & 0.43 & 40.09 & 54.74 & 265.87 \\
\hline 40 & 22.30 & 3.77 & 1.00 & 49.61 & 92.95 & 629.64 \\
\hline $\begin{array}{l}\text { continu } \\
\text { on nex } \\
\text { page }\end{array}$ & & & & & & \\
\hline
\end{tabular}


Table 6: continued

\begin{tabular}{|c|c|c|c|c|c|c|}
\hline $\begin{array}{l}\text { Depth } \\
(\mathrm{cm})\end{array}$ & $\mathrm{Al}$ & $\mathrm{K}$ & $\mathrm{Ti}$ & $\mathrm{Co}$ & $\mathrm{Ni}$ & $\mathrm{Ba}$ \\
\hline 60 & 22.87 & 3.74 & 1.00 & 44.51 & 81.83 & 624.06 \\
\hline 80 & 23.67 & 3.84 & 1.06 & 25.08 & 68.19 & 597.80 \\
\hline 100 & 22.83 & 3.75 & 1.00 & 25.56 & 65.33 & 626.40 \\
\hline 120 & 23.10 & 3.76 & 1.06 & 27.61 & 74.06 & 624.73 \\
\hline 140 & 24.14 & 3.98 & 1.03 & 23.87 & 64.82 & 666.42 \\
\hline 160 & 24.13 & 3.98 & 1.02 & 24.02 & 65.15 & 667.03 \\
\hline 180 & 24.57 & 4.08 & 1.05 & 27.66 & 73.52 & 695.30 \\
\hline 200 & 24.03 & 3.88 & 1.00 & 26.37 & 69.57 & 650.20 \\
\hline 220 & 25.41 & 4.21 & 1.09 & 23.45 & 56.92 & 690.73 \\
\hline 240 & 24.51 & 4.01 & 1.04 & 25.36 & 70.33 & 668.63 \\
\hline 260 & 24.70 & 4.12 & 1.06 & 26.79 & 65.52 & 695.13 \\
\hline 280 & 25.09 & 4.10 & 1.05 & 21.28 & 56.08 & 674.47 \\
\hline 300 & 23.73 & 3.92 & 1.06 & 26.13 & 65.38 & 658.18 \\
\hline 320 & 23.97 & 3.96 & 1.06 & 22.87 & 62.66 & 674.32 \\
\hline 340 & 24.25 & 3.90 & 1.05 & 23.69 & 67.88 & 648.63 \\
\hline 360 & 24.74 & 4.05 & 1.08 & 27.24 & 66.99 & 674.07 \\
\hline 380 & 24.89 & 4.09 & 1.05 & 23.53 & 63.67 & 687.62 \\
\hline 400 & 25.28 & 4.10 & 1.07 & 22.01 & 60.39 & 677.77 \\
\hline 420 & 25.30 & 3.94 & 1.05 & 20.51 & 59.14 & 665.27 \\
\hline 440 & 26.06 & 4.24 & 1.07 & 21.12 & 65.18 & 709.96 \\
\hline 460 & 25.31 & 3.95 & 1.03 & 16.86 & 54.90 & 676.80 \\
\hline 480 & 24.55 & 3.96 & 1.08 & 17.04 & 56.47 & 675.72 \\
\hline 500 & 23.31 & 3.70 & 0.95 & 19.84 & 54.56 & 625.34 \\
\hline 520 & 24.36 & 3.86 & 1.04 & 21.68 & 60.80 & 660.32 \\
\hline 540 & 24.00 & 4.00 & 1.03 & 20.92 & 49.83 & 675.16 \\
\hline 560 & 25.50 & 4.21 & 1.11 & 19.22 & 53.81 & 694.27 \\
\hline
\end{tabular}


Table 6: continued

\begin{tabular}{lllllll}
\hline $\begin{array}{l}\text { Depth } \\
(\mathrm{cm})\end{array}$ & $\mathrm{Al}$ & $\mathrm{K}$ & $\mathrm{Ti}$ & $\mathrm{Co}$ & $\mathrm{Ni}$ & $\mathrm{Ba}$ \\
\hline \hline 580 & 24.38 & 4.07 & 1.03 & 18.90 & 50.77 & 694.41 \\
600 & 23.65 & 3.83 & 1.00 & 17.61 & 52.36 & 648.93 \\
620 & 27.61 & 4.53 & 1.15 & 21.29 & 58.55 & 757.73 \\
640 & 23.94 & 4.00 & 0.98 & 24.96 & 56.25 & 700.33 \\
660 & 22.83 & 3.97 & 1.01 & 32.36 & 64.47 & 704.44 \\
680 & 23.51 & 4.04 & 1.01 & 32.18 & 63.07 & 717.06 \\
700 & 22.41 & 3.76 & 1.00 & 29.52 & 64.09 & 681.81 \\
720 & 22.15 & 3.83 & 0.97 & 26.24 & 56.33 & 679.47 \\
740 & 22.03 & 3.77 & 0.99 & 34.86 & 62.89 & 670.49 \\
760 & 22.23 & 3.82 & 0.99 & 24.67 & 56.95 & 682.50 \\
780 & 22.52 & 3.85 & 1.01 & 39.03 & 60.55 & 677.27 \\
800 & 22.32 & 3.83 & 0.99 & 41.11 & 62.00 & 675.94 \\
820 & 22.38 & 3.80 & 0.97 & 53.31 & 55.01 & 671.13 \\
840 & 22.63 & 3.28 & 0.99 & 21.23 & 60.44 & 572.60 \\
860 & 23.57 & 3.57 & 1.05 & 20.54 & 56.13 & 629.54 \\
880 & 22.67 & 3.64 & 0.98 & 17.79 & 48.51 & 640.86 \\
900 & 22.58 & 3.56 & 1.00 & 18.84 & 48.24 & 620.59 \\
920 & 23.38 & 3.81 & 1.10 & 18.65 & 45.47 & 663.89 \\
940 & 23.02 & 3.25 & 1.05 & 24.11 & 65.62 & 584.37 \\
960 & 22.64 & 3.64 & 1.06 & 18.56 & 45.67 & 649.10 \\
980 & 23.21 & 3.68 & 1.09 & 21.44 & 56.50 & 659.44 \\
1000 & 20.26 & 2.98 & 0.90 & 22.06 & 53.96 & 520.37 \\
\hline & & & & & &
\end{tabular}




\section{References}

Armstrong, H. A., Coe, A. L., 1997. Deep-sea sediments record the geophysiology of the late Ordovician glaciation. Journal of the Geological Society, London 154, 929-934.

Armstrong, H. A., Owen, A. W., 2002. Euconodont palaeobiogeography and the closure of the Iapetus Ocean. Geology 30 (12), 1091-1094.

Arndt, S., Brumsack, H.-J., Wirtz, K. W., 2006. Cretaceous black shales as active bioreactors; a biogeochemical model for the deep biosphere encountered during ODP Leg 207 (Demerara Rise). Geochimica et Cosmochimia Acta 70 (2), 408-425.

Arthur, M., Sageman, B., 1994. Marine black shales: Depositional mechanisms and environments of ancient deposits. Annual Review of Earth and Planetary Sciences 22, 499-551.

Beckmann, B., Flögel, S., Hofmann, P., Schulz, M., Wagner, T., 2005. Orbital forcing of Cretaceous river discharge in tropical Africa and ocean response. Nature 437 (8), 241-244.

Berger, W. H., Smetacek, V. S., Wefer, G., 1989. Productivity of the Oceans: Present and Past. Wiley Interscience, New York, pp. 471.

Berner, R. A., 1994. Geocarb II: a revised model for atmospheric $\mathrm{CO}_{2}$ over Phanerozoic time. American Journal of Science 294, 56-91.

Berner, R. A., Kothavala, Z., 2001. Geocarb III: a revised model for atmospheric $\mathrm{CO}_{2}$ over Phanerozoic time. American Journal of Science 301 (2).

Berry, W. B. N., Wilde, P., 1978. Progressive ventilation of the oceans; an explanation for the distribution of the lower Paleozoic black shales. American Journal of Science 278 (3), 257-275.

Bevins, R. E., Merriman, R. J., 1988. Compositional controls on coexisting prehnite actinolite and prehnite pumpellyite facies assemblages in the TalY-Fan metabasite intrusion, North Wales: - implications for Caledonian metamorphic field gradients. Journal of Metamorphic Geology 6, 17-39.

Bevins, R. E., Robinson, D., 1988. Low grade metamorphism in the Welsh Basin Lower Palaeozoic succession: An example of diastathermal metamorphism? Journal of the Geological Society, London 145, 363-366.

Bjerrum, C. J., Bendtsen, J., Legarth, J. J. F., 2006. Modeling organic carbon burial during sea level rise with reference to the Cretaceous. Geochemistry, Geophysics, Geosystems - G (super 3) 7 (5), doi:10.1029/2005GC001032.

Boening, P., Brumsack, H.-J., Boettcher, M. E., Schnetger, B., Kriete, C., Borchers, S. L., 2004. Geochemistry of peruvian near-surface sediments. Geochimica et Cosmochimia Acta 68 (21), 4429-4451.

Borchers, S. L., Schnetger, B., Böning, P., Brunsack, H.-J., 2005. Geochemical signatures of the Namibian diatom belt: Perennial upwelling and intermittent anoxia. Geochemistry, Geophysics, Geosystems - G (super 3) 6 (6), doi:10.1029/2004GC000886.

Bottrell, S. H., Greenwood, P. B., Yardley, B. W. D., Shepherd, T. J., Spiro, B., 1990. Metamorphic and post-metamorphic fluid-flow in the low-grade 
rocks of the Harlech Dome, North Wales. Journal of Metamorphic Geology 8, 131-143.

Brumsack, H.-J., 2006. The trace metal content of recent organic carbon-rich sediments: implications for Cretaceous black shale formation. Palaeogeography, Palaeoclimatology, Palaeoecology 232, 344-361.

Brunsack, H.-J., 1989. Geochemistry of Recent TOC-rich sediment from the Gulf of California and the Black sea. Geologische Rundschau 78 (3), 851882.

Cave, R., 1965. The Nod Glas sediments of Caradoc age in North Wales. Geological Journal 4, 279-298.

Davies, J. R., Fletcher, C. J. N., Pratt, W. T., Schofield, D. I., Waters, R. A., Woodhall, D. G., Wilby, P. R., Wilson, D., 2004. Geology of the Builth Wells district - a brief explanation of the geological map. Sheet explanation of the British Geological Survey. 1 : 50000 Sheet 196 (England and Wales). British Geololical Survey.

Davies, J. R., Fletcher, C. J. N., Waters, R. A., Wilson, D., Woodhall, D. G., Zalaziewicz, J. A., 1997. Geology of the country around Llanilar and Rhayader. Memoir of the British Geological Survey, Sheets 178 and 179 (England and Wales). The Stationary Office, London, p. 267.

Davies, J. R., Sheppard, T. H., Waters, R. A., Wilson, D., 2006. Geology of the Llangranog district - a brief explanation of the geological map. Sheet explanation of the British Geological Survey. 1 : 50000 Sheet 194 (England and Wales). British Geololical Survey, p. sw.

Davies, J. R., Waters, R. A., Wilby, P. R., Williams, Wilson, D., 2003. Geology of the Cardigan and Dinas Island district - a brief explanation of the geological map. Sheet explanation of the British Geological Survey. 1 : 50000 Sheet 193 (including part of Sheet 210) Cardigan and Dinas Island (England and Wales). British Geololical Survey, p. 26.

De La Rocha, C. L., 2004. The biological pump. In: Elderfield, H. (Ed.), The Oceans and Marine Geochemistry. Vol. 6 of Treatise on Geochemistry. Elsevier Pergamon, pp. 83-112.

Ekdale, A. A., Mason, T., 1988. Characteristic trace-fossil associations in oxygen-poor sedimentary environments. Geology 16, 720-723.

Fettes, D. J., Long, C. B., Bevins, R. E., Max, M. D., Olover, G. J. H., Primmer, T. J., Thomas, L. J., Yardley, B. W. D., 1985. Grade and time of metamorphism in the Caledonide Orogen of Britain and Ireland. In: Harris, A. L. (Ed.), The nature and timing of orogenic activity in the caledonian rocks of the British Isles. Blackwell for the Geological Society of London, U.K.

Fortey, R. A., Harper, D. A. T., Ingham, J. K., Owen, A. W., Parkes, M. A., Rushton, A. W. A., Woodcock, N. H., 2000. A revised correlation of Ordovician rocks in the British Isles. Tech. rep., Geological Society of London Special Report no. 24, 83 pp.

Freeman, K. H., 2001. Reviews in Mineralogy and Geochemistry. Vol. 43. Mineralogical Society of America and Geochemical Society, Washington, DC, 
United States, Ch. 11. Isotopic biogeochemistry of marnie organic carbon., pp. 579-605.

Freeman, K. H., Hayes, J. M., 1992. Fractionation of carbon isotopes by phytoplankton and estimates of ancient $\mathrm{CO}_{2}$ levels. Global Biogeochemical Cycles 6, 185-198.

Goericke, R., 1994. Variations in marine $\delta^{13} \mathrm{c}$ with latitude, temperature and dissolved $\mathrm{CO}_{2}$ in the world ocean. Global Biogeochemical Cycle 8, 85-90.

Goericke, R., Montoya, J. P., Fry, B., 1994. Physiology of isotope fractionation in algae and cyanobacteria. In: Lajtha, K., Michener, B. (Eds.), Stable isotopes in ecology. Blackwell Scientific, Boston, pp. 199-233.

Hannigan, R. E., Basu, A., 1998. Late diagenetic trace element remobilization in organic-rich black shales of the Taconic foreland basin of Quebec, Ontario and New York. In: J. Schieber, W. Z., Sethi, P. S. (Eds.), Shales and Mudstones vol. II. pp. 209-233.

Hay, W. W., Brock, J. C., 1992. Temporal variation in intensity of upwelling off southwest africa. In: Summerhayes, C. P., P. W. L., Emeis, K. C. (Eds.), Upwelling Systems: evolution since the Early Miocene. Geological Society Special Publication No. 64, pp. 463-497.

Hermann, A. D., Haupt, B. J., Patzkowsky, M. E., Seidov, D., Slingerland, R. L., 2005. Response of Late Ordovician paleoceanography to changes in sea level, continental drift and atmospheric $p \mathrm{CO}_{2}$ : potential causes for long-term cooling and glaciation. Palaeogeography, Palaeoclimatology, Palaeoecology 210, 385-401.

Hermann, A. D., Patzkowsky, M. E., Pollard, D., 2004. The impact of paleogeography, $p \mathrm{CO}_{2}$, poleward ocean heat transport and sea-level change on global cooling during the Late Ordovician. Palaeogeography, Palaeoclimatology, Palaeoecology 206, 59-74.

Hofmann, M., Wolf-Gladrow, D. A., Takashashi, T., Sutherland, S. C., Six, K. D., Maier-Reimer, E., 2000. Stable carbon isotope distribution of particulate organic matter in the ocean: a model study. Marine Chemistry 72 , $131-150$.

Hollander, D. J., McKenzie, J. A., 1991. $\mathrm{CO}_{2}$ control on carbon isotope fractionation during aqueous photosynthethesis: a palaeo- $\mathrm{pCO}_{2}$ barometer. Geology 19, 929-932.

Ingall, E. D., Bustin, R. M., Van Cappellen, P., 1993. Influence of water column anoxia on the burial and preservation of carbon and phosphorus in marine shales. Geochimica et Cosmochimia Acta 57 (2), 303-316.

Jahnke, R. A., 1990. Ocean flux studies: a status report. Review of Geophysics 28, 381-398.

Jones, B., Manning, D. A. C., 1994. Comparison of geochemical indices used for the interpretation of palaeoredox conditions in ancient mudstones. Chemical Geology 111 (1-4), 111-129, .

Kuypers, M. M. M., Lourens, L. J., Rijpstra, W., Irene, C., Pancost, R. D., Nijenhuis, I. A., Damste, J. S., 2004. Orbital forcing of organic carbon burial in the proto-North Atlantic during oceanic anoxic event 2. Earth and Plan- 
etary Science Letters 228 (3-4), 465-482.

Kuypers, M. M. M., Pancost, R. D., Nijenhuis, I. A., Sinninghe Damsté, J. S., 2002. Enhanced productivity led to increased organic carbon burial in the euxinc North Atlantic basin during the late Cenomanian oceanic anoxic event. Paleoceanography 17 (4).

Leggett, J. K., 1980. British Lower Palaeozoic black shales and their palaeooceanographic significance. Journal of the Geological Society, London 137, $139-156$.

Lehmann, M. F., Bernasconi, S. M., Barbieri, A., McKenzie, J. A., 2002. Preservation of organic matter and alteration of its carbon and nitrogen isotope composition during simulated and in situ early sedimentary diagenesis. Geochimica et Cosmochimia Acta 66 (20), 3573-3584.

Lev, S. M., Filer, J. K., Tomascak, P., 2008. Orogenesis vs. diagenesis: Can we use organic-rich shales to interpret the tectonic evolution of a depositional basin? Earth Science Reviews 86 (1-4), 1-14.

Löwemark, L., Schönfeld, J., Werner, F., Scäfer, P., 2004. Trace fossils as a paleoceanographic tool: evidence from late Quaternary sediments of the southwestern Iberian margin. Marine Geology 204, 27-41.

Maslin, M. A., Swann, G. E. A., 2005. Isotopes in Palaeoenvironmental Research. Springer, Ch. 6. Isotopes in marine sediments, pp. 227-269.

McCann, T., 1990. Distribution of Ordovician-Silurian ichnofossil assemblages in Wales - implications for Phanerozoic ichnofaunas. Lethaia 23, 243-255.

Meyers, P. A., Arnaboldi, M., 2005. Trans-Mediterranean comparison of geochemical productivity proxies in a mid-Pleistocene interrupted sapropel. Palaeogeography, Palaeoclimatology, Palaeoecology 222, 313-328.

Milodowski, A. E., Zalasiewicz, J. A., 1991. Redistribution of rare earth elements during diagenesis of turbidite/hemipelagite mudrock sequences of Llandovery age from central Wales. In: Morton, A. C., Todd, S. P., Houghton, P. D. (Eds.), Developments in sedimentary provenance studies. Vol. 57 of Geological Society Special Publication. Geological Society, London, pp. 101-124.

Nara, F., Tani, Y., Soma, Y., Soma, M., Naraoka, H., Watanabe, T., Horiuchi, K., Kawai, T., Oda, T., T., N., 2005. Response of phytoplankton productivity to climate change recorded by sedimentary photosynthetic pigments in Lake Hovsgol (Mongolia) for the last 23,000 years. Quaternary International 136, 71-81.

Nielsen, A. T., 2004. Chapter 10. ordovician sea level changes; a Balroscandian perspective. In: Webby, B. D., Droser, M. L., Paris, F., Percival, I. (Eds.), The Great Ordovician Biodiversification Event. New: Columbia University Press, pp. 84-93.

Ottley, C. J., Pearson, D. G., Irvine, G. J., 2003. A routine method for the dissolution of geological samples for the analysis of REE and trace elements via ICP-MS. In: Holland, J. G., Tanner, S. D. (Eds.), Plasma Source Mass Spectrometry: Applications and Emerging Technologies. Cambridge: Royal Society of Chemistry., pp. 221-230. 
Page, A., Zalaziwicz, J., Williams, M., Popov, L., 2007. Were transgressive black shales a negative feedback modulating glacioeustacy in the Early Palaeozoic icehouse? In: Williams, M., H. A. M. G. F. J., Schmidt, D. N. (Eds.), Deep-Time Perspectives on Climate Change: Marrying the Signal from Computer Models and Biological Proxies. The Micropalaeontological Society Special Publications. The Geological Society, London, pp. 123-156. Pancost, R. D., Freeman, K. H., Wakeham, S. G., 1999. Controls on the carbon-isotope compositions of compounds in Peru surface waters. Organic Geochemistry 30 (5), 319-340.

Parrish, J. T., 1982. Upwelling and petroleum source beds, with reference to Palaeozoic. AAPG Bulletin 66, 750-774.

Peacor, D. R., Voveney, R. M. J., Zhao, G., 2000. Authigenic illite and organic matter; the principal hosts of vanadium in the Mecca Quarry Shale at Velpen, Indiana. Clay and Clay Minerals 48 (3), 311-316.

Peeters, F. J. C., Brummer, G.-J. A., Ganssen, G., 2002. The effect of upwelling on the distribution and stable isotope composition of Globigerina bulloides and Globigerinoides ruber (planktic Foraminifera) in modern surface waters of the NW Arabian Sea. In: Ganssen, G. (Ed.), From process studies to reconstruction of the palaeoenvironment; advances in palaeoceanography, Global and Planetary Change. Vol. 34. Elsevier, Amsterdam, Netherlands, pp. 269-291.

Peters-Kottig, W., Strauss, H., Kerp, H., 2006. The land plant delta ${ }^{13} \mathrm{C}$ record and plant evolution in the late Palaeozoic. Palaeogeography, Palaeoclimatology, Palaeoecology 240 (1-2), 237-252.

Pope, M. C., Steffen, J. B., 2003. Widespread, prolonged late Middle to Late Ordovician upwelling in North America: a proxy record of glaciation? Geology 33 (6), 214-215.

Prakash Babu, C., Brumsack, H.-J., Schnetger, B., Boettcher, M. E., 2002. Barium as a productivity proxy in continental margin sediments; a study from eastern Arabian Sea. Marine Geology 184 (3-4), 189-206.

Pugh, W. J., 1923. The geology of the district around Corris and Aberllefenni (Merionethshire). Quarterly Journal of the Geological Society, London 85, 242-306.

Rhoads, D. C., Morse, J. W., 1971. Evolutionary and ecologic significance of oxygen deficient marine basin. Lethaia 4, 413-428.

Rind, D., 1998. Latitudinal temperature gradients and climate change. Journal of Geophysical Research 103 (D6), 5943-5971.

Roberts, B., Merriman, R. J., Hirons, S. R., Fletcher, C. J. N., Wilson, D., 1996. Synchronous very low-grade metamorphism, contractions and inversion in the central part of the Welsh lower Palaeozoic basin. Journal of the Geological Society, London 153, 277-285.

Roberts, B., Merriman, R. J., Pratt, W., 1991. The influence of strain, lithology and stratigraphical depth on white mice (Illite) crystallinity in mudrocks from the vicinity of the Corris Slate Belt, Wales: - implications for the timing of metamorphism in the Welsh Basin. Geological Magazine 128, 
633-645.

Robinson, D., Bevins, R. E., 1986. Incipient metamorphism in the Lower Palaeozoic marginal basin of Wales. Journal of Metamorphic Petrology 4, 101-113.

Ruddiman, W. F., 2000. Earth's climate: past and future. W. H. Freeman and Company, New York.

Sageman, B. B., Wignall, P. B., Kauffman, E. G., 1991. Biofacies models for organic-rich facies: tool for paleoenvironmental analysis. In: G. Einsele, W. R., Seilacher, A. (Eds.), Cycles and Events in Stratigraphy. Springer Verlag, Berlin, pp. 542-564.

Savrda, C. E., 1995. Ichnologic applications in paleoceanographic, paleoclimatic and sea-level studies. Palaios 10, 565-577.

Savrda, C. E., Bottjer, D. J., 1994. Ichnofossils and ichnofabrics in rythmically bedded pelagic/hemipelagic carbonates: Recognition and evaluation of benthic redox and scour cycles. In: Orbital forcing and Cyclic Sequences. International Association of Sedimentologists, Special Publication, pp. 195210.

Shimmield, G. B., 1992. Can sediment geochemistry record changes in coastal upwelling palaeoproductivity? In: Summerhayes, C. P., Prell, W. L., Emeis, K. C. (Eds.), Upwelling systems: Evolution since the Eary Miocene. Geological Society Special Publication 64. The Geological Society, London, pp. 29-46.

Sobarzo, M., Bravo, L., Donoso, D., Garcés-Vargas, J., Schneider, W., 2007. Coastal upwelling and seasonal cycles that influence the water column over the continental shelf off central Chile. Progress in OceanographyIn press.

Stow, D. A. V., Wetzl, A., 1987. Hemiturbidite: a new type of deep-water sediment. In: Proceedings of the Ocean Drilling Program, distal Bengal Fan; covering Leg 116 of the drilling vessel JOIDES Resolution, Colombo, Sri Lanka, to Colombo, Sri Lanka, sites 717-719, 2 July 1987-19 August 1987. Vol. 116. Texas A and M University, Ocean Drilling Program, United States, pp. 25-34.

Temple, J. T., Cave, R., 1992. Preliminary report on the geochemistry and mineralogy of the Nod Glas and related sediments (Ordovician) of Wales. Geological Magazine 129 (5), 589-594.

Tribovillard, N., Ramdani, A., Trentesaux, A., 2005. Controls on organic accumulation in upper jurassic shales of northwestern europe as inferred from trace-metal geochemistry. In: Harris, N. B. (Ed.), The deposition of organiccarbon-rich sediments: models, mechnisms and consequences. Society for Sedimentary Geology Special Publication No. 82., pp. 145-164.

Twichell, S. C., M. P. A., Diester-Haass, L., 2002. Significance of high C/N ratios in organic carbon-rich Neogene sediments under the Benguela Current upwelling system. Organic Geochemistry 33, 715-722.

Tyson, R. V., 1995. Sedimentary organic Matter: Organic Facies and Palynofacies. Chapman and Hall, London.

Underwood, C. J., Crowley, S. F., Marshall, J. D., Brenchley, P. J., 1997. 
High-resolution carbon isotope stratigraphy of the basal Silurian Stratotype (Dob's Linn, Scotland) and its global correlation. Journal of the Geological Society, London 154, 709-718.

Vandenbroucke, T. R. A., Vanmeirhaeghe, J., 2007. Acta palaeontologica Sinica 46, 497-501.

5 Vilinski, J. C., Domack, E., 1998. Temporal changes in sedimentary organic carbon from the Ross Sea Antarctica: inferred changes in ecosystems and climate. Eos (Transactions, American Geophysical Union) 79, 157.

Warnnig, B., Brumsack, H.-J., 2000. Trace metal signatures of eastern mediterranean sapropels. Palaeogeography, Palaeoclimatology, Palaeoecology 158 (3-4), 293-309.

Webby, B. D., Droser, M. L., Paris, F., Percival, I., 2004. The Great Ordovician Biodiversification Event. New: Columbia University Press, p. 484.

Wignall, P., 1991. Model for transgressive black shales? Geology 19, 167-170.

Woodcock, N. H., 1990. Sequence stratigraphy of the Palaeozoic Welsh Basin. Journal of the Geological Society, London 147, 537-547.

${ }_{76}$ Yapp, C. J., Poths, H., 1992. Ancient atmospheric $\mathrm{CO}_{2}$ pressures inferred from natural goethites. Nature 353, 342-344.

878 Yarincik, K. M., Murray, R. W., Peterson, L. C., 2000. Climatically sensitive

879 eolian and hemipelagic depsition in the Cariaco Basin, Venezuela, over the past 578,000 years. Results from Al/Ti and K/Al. 15, 210-228. 